\title{
The Netherlands: The Pragmatics of a Flexible, Europeanised Constitution
}

\author{
Leonard Besselink and Monica Claes
}

\begin{abstract}
The Constitution of the Netherlands, which dates back to 1814-15, is an evolutionary constitution, based on incremental historical developments. A notable feature is that the Constitution bans constitutional review of Acts of Parliament and of treaties. A bill of rights was introduced in 1983; however, it omits a number of rights included in the ECHR and the EU Charter. Constitutional rights are not justiciable, in the sense that they cannot be invoked against primary legislation. The ECHR and the EU Charter are often regarded as providing stronger protection. Due to historical reasons, the notions of sovereignty and the people as the ultimate source of public authority have been absent in the Dutch legal and public discourse. The Dutch Constitution does not have the centrality to public debate that constitutions have in other Western countries. A salient feature of the Constitution is that although it does not mention the EU or the ECHR, it opens the legal order for both nearly unconditionally, granting them primacy over any conflicting national law. Contestation and conflict sensitive and fundamental constitutional issues are rare in the courtroom or in legal terms. Court cases have raised the question whether national institutions can derive powers from an EU measure directly, e.g. when
\end{abstract}

Leonard F. M. Besselink is Professor of Constitutional Law at the University of Amsterdam. e-mail: 1.besselink@uva.nl.

Monica Claes is Professor of European and Comparative Constitutional Law at the Law Faculty of Maastricht University. e-mail: Monica.Claes@maastrichtuniversity.nl.

This paper was finalised in June 2016, and only occasionally have later developments been incorporated.

All websites accessed 30 June 2016.

\footnotetext{
L. Besselink $(\bowtie)$

University of Amsterdam, Amsterdam, The Netherlands

e-mail: 1.besselink@uva.nl
}

M. Claes

Maastricht University, Maastricht, The Netherlands

e-mail: Monica.Claes@maastrichtuniversity.nl

(C) The Author(s) 2019

A. Albi and S. Bardutzky (eds.), National Constitutions in European

and Global Governance: Democracy, Rights, the Rule of Law,

https://doi.org/10.1007/978-94-6265-273-6_5 
imposing the obligation to repay EU subsidies, and whether an international technical standard that is available only after payment can be legally binding on individuals.

Keywords The Dutch Constitution - Amendment of the Constitution regarding EU and international law/Europeanisation of the Constitution - The Supreme Court of the Netherlands - Evolutionary constitutionalism - Ban on constitutional review of Acts of Parliament and of treaties - European Arrest Warrant and extraditions Data Retention Directive - Fundamental rights - ECHR - EU Charter Absence of discourse on sovereignty and people as the source of public authority Repayment of subsidies - Binding nature of unpublished international technical standards

\section{Constitutional Amendments Regarding EU Membership}

\subsection{Constitutional Culture}

In this report we explain some of the apparent paradoxes pertaining to the constitutional system of the Netherlands. For a proper understanding of the constitutional situation in the Netherlands, one should be acutely aware of the distinction between the formal constitution, of which the Grondwet (literally 'Basic Law') is the central part, and the substantive constitutional rules contained in the other sources that are generally considered to be part of Netherlands' constitutional law, which include international and European treaties providing for fundamental rules concerning the exercise of public authority, in particular human rights treaties, and certain general principles of constitutional law in a democratic state under the rule of law. The Grondwet does not mention Europe, neither the European Union nor the European Convention on Human Rights, although - as we explain in Sect. 1.2.1 - it opens nearly unconditionally the legal order for both, granting them primacy over any conflicting national law. Hence, in the absence of any mention of Europe, the constitutional order turns out to be strongly Europeanised. Another paradox is that the Grondwet is entrenched and its amendment cumbersome (see Sect. 1.2.2), but the primacy of European law and directly effective international law, combined with a constitutional practice and political culture in which the formal constitution does not occupy an important place (as we explain in Sects. 1.1.1-1.1.2 and 1.3), provide it with great flexibility. We sketch in Sect. 2 the constitutional pragmatics with regard to specific constitutionally sensitive topics, such as fundamental rights protection and the constitutional principles concerning the rule of law with regard to the European Arrest Warrant and Data Protection. In Sect. 3, we describe briefly how this opens the legal order to the various forms of global governance. 
1.1.1-1.1.2 The Constitution of the Netherlands is of the historical type: it is based on more or less incremental developments. ${ }^{1}$ The current formal constitution, the Grondwet, ${ }^{2}$ is generally considered to date back to the one issued in 1814, which constituted a constitutional monarchy in the Netherlands, and to 1815 , when this was amended to implement the results of the Vienna Congress. ${ }^{3}$ The 1848 revision, adopted against the backdrop of revolutions in Europe, introduced a system of parliamentary democracy, and defines the constitutional system of the Netherlands to date. The year 1848 is also when Art. 115 was adopted, which stated that 'statutes are inviolable'. In 1983 the text of the Constitution was modernised and simplified, and a bill of rights was introduced in the opening chapter of the Constitution. Article 115 was reformulated and renumbered, so that Art. 120 now provides that 'Courts shall not review the constitutionality (grondwettigheid) of Acts of Parliament and treaties', where grondwettigheid refers to the compatibility of Acts of Parliament and treaties with the provisions of the Grondwet.

The Dutch Constitution can be characterised as an 'open constitution': it does not set up a closed system. It is generally agreed that the broader constitution is made up of several components, of which the written document entitled 'Constitution for the Kingdom of the Netherlands' is only one, be it the central, part. In the Dutch language, a distinction can be made between the document containing the formal Constitution ('Grondwet') and the broader category of fundamental rules and principles governing the relationships between the state organs, between the domestic and the international legal orders and between the state and the individuals ('constitutie'). This resembles the distinction between Grundgesetz and Verfassung in German constitutional law. In addition to the Grondwet, the constitutie also includes unwritten principles, constitutional conventions, some international treaties, the Charter of the Kingdom, ${ }^{4}$ and certain organic laws and decrees. $^{5}$

\footnotetext{
${ }^{1}$ Besselink 2014b, pp. 1189 et seq.

${ }^{2}$ For provisions prior to 2004, the translation used is the version by Besselink 2004b; later provisions are our own, given certain shortcomings of the English version published by the Government of the Netherlands at https://www.government.nl/documents/regulations/2012/10/18/ the-constitution-of-the-kingdom-of-the-netherlands-2008.

${ }^{3}$ The Republic of the United Provinces (1581-1795) did not have a single written constitution in the modern sense of the word, although there were several constitutional documents and charters such as The Union of Utrecht (1579) and the Act of Abjuration (1581). In 1798, a constitutional document, the Staatsregeling voor het Bataafse Volk, established the Batavian Republic, but it was short-lived and abolished already in 1801 .

${ }^{4}$ The Charter operates as the basic law of the Kingdom of the Netherlands, which includes the country in Europe (the Netherlands to which the Caribbean islands of Bonaire, St. Eustatius and Saba were added in 2010), as well as (currently) Aruba, Curaçao and Sint Maarten. It ranks higher than the Constitution.

${ }^{5}$ These are normal Acts of Parliament (and some royal decrees) and do not have a higher rank or stronger force of law. They are considered 'organic' because they concern the organisation of the state and provide an elaboration of constitutional provisions from the Grondwet or otherwise unregulated constitutional matters. Examples are the Act on Municipalities and the Act on the
} 
The Constitution (Grondwet) is unostentatious, simple, sober and short. It contains no grand concepts such as sovereignty, ${ }^{6}$ no preamble, no invocatio dei, no Staatszielen. It does not mention the symbols of the state, the flag, the anthem or the motto, or any other elements that would be considered Verfassungskitsch. The main reason for this is that the Netherlands Constitution is not revolutionary, that is to say adopted to make a clear break with the past, nor does it sanction the sovereignty of the state or establish a new regime. It is rather an evolutionary, 'long-term constitution', based on more or less incremental historical developments, aimed at codifying a state of affairs, rather than modifying the political system for the future. ${ }^{7}$ In 2006, the National Convention promoted the idea of a preamble to the Constitution, in order to give expression to some evident fundamental values of Dutch society and strengthen the Dutch national identity. ${ }^{8}$ The $2009-2010$ Constitutional Committee, however, did not see the added legal and political value of such a preamble, and pointed to the fact that it was unlikely that consensus would be found on its text, for instance on whether it should contain an invocatio dei. This also has to do with the fact that the Netherlands sees itself as a country of 'minorities' that keep one another in check. This consociationalism implies that Dutch politics and governance are characterised by a common striving for broad consensus on important issues, within both the political community and society as a whole. The Constitution is only to a limited extent considered to express the "national identity' of the state, the political community or the people of the Netherlands. The values it protects are, on the whole, values that the Netherlands shares with other nations.

The 2009-2010 Constitutional Committee did recommend the adoption of a general clause that would express the most fundamental features of the Constitution - which have never been written in the constitutional text before - namely that the Netherlands is a democratic state under the rule of law, that the government respects and protects human dignity, fundamental rights and fundamental principles, and that public authority can be exercised only pursuant to law.

This part of the advice of the Committee was picked up by the Upper House, and a bill adding a general preliminary clause to the text of the Constitution has recently been introduced in Parliament. Yet, the text proposed reads very differently, stating

Provinces, and the royal decree providing for the rules of procedure of the Council of Ministers. The rules of procedure for the States-General (the Netherlands Parliament) are autonomous decisions of each of the two Houses of Parliament that provide detailed rules on the parliamentary system and its practice.

${ }^{6}$ On (absence of) the concept of sovereignty in the Dutch constitutional discourse on European integration, see De Witte 2004.

${ }^{7}$ Besselink 2004a, b, p. 18.

${ }^{8}$ Nationale Conventie, Hart voor de publieke zaak. Aanbevelingen van de Nationale Conventie voor de 21e eeuw (Caring for the pubic cause: recommendations of the National Convention for the 21st century), September 2006, pp. 42-43. 
merely that '[t]he Constitution guarantees democracy, the rule of law and fundamental rights'?

In the Dutch constitutional culture, the Constitution and constitutional law play only a limited role in politics and in the public debate. ${ }^{10}$ In this respect, the Constitution is not 'a living document': it is considered first and foremost as a document for the government and public authorities, not for society and the citizens. But even in the legal scene, the Constitution does not play the lead role: issues of constitutionality of legislation are often downplayed as they are not justiciable in any case, while compatibility with fundamental principles is often phrased in terms of compatibility with human rights treaties, such as the European Convention on Human Rights (ECHR). The legal and political authority of the Constitution is thus overshadowed by European and international (human rights) law (mainly ECHR and EU law), which operates as a substitute constitution. Even the Council of State, the Government's prime advisor on the legality of legislation, does not place the Constitution and constitutional law at the centre of attention, but rather looks to the ECHR and other international treaties to draw the legal lines that should not be crossed. The limits of governmental and legislative action are found in international treaties, which were only meant as a European minimum level below which no state should go, rather than within the country's own constitution. Paradoxically, this silence with regard to the Constitution and its underlying values is often seen as desirable and good: the Constitution reflects the constitutional settlements of the past ${ }^{11}$ political compromises that should not be too easily challenged. Silence on constitutional matters is seen as a sign of constitutional peace and harmony. ${ }^{12}$ This is reinforced by an uncertain attitude relating to constitutional interpretation and contestation: the Constitution says what it says, no more and no less, and constitutional change should be brought about by constitutional amendment, often piecemeal, 'to keep the Constitution up to date'. Neither the Legislature, nor the Council of State, the Government nor the courts see it as their role to develop a 'living Constitution', to take the lead in adapting it to the changes of time through interpretation, or indeed to present themselves as the 'ultimate interpreter' of the

\footnotetext{
9 'De Grondwet waarborgt de democratie, de rechtsstaat en de grondrechten'. This Bill was introduced in the Lower House on 9 July 2016, TK [Parliamentary Documents] 34 516, Nos. 1-3. ${ }^{10}$ See e.g. Oomen 2009, pp. 55-79; Oomen and Lelieveldt 2008, pp. 577-578.

${ }^{11}$ In his speech at the occasion of the presentation of the report of the Royal Committee on the Constitution, Donner, the current vice president of the Council of State, then Minister for Justice, labelled the Constitution as 'gestold verleden', 'history solidified', and expressed the view that the Constitution mainly settles political conflicts of the past. It offers a legal framework, rather than an inspiration for the government or even less so for society. See https://www.rijksoverheid.nl/ documenten/toespraken/2010/11/11/toespraak-minister-donner-bij-in-ontvangst-nemen-adviesstaatscommissie-grondwet.

${ }^{12}$ Tijn Kortmann, a leading scholar in constitutional law, considered the lack of discussion on the Constitution a sign of its strength: 'a constitution that is not "living" is not necessarily dead as a doornail', but may be well-accepted in the hearts and minds of politicians, civil servants and the general public. On the latter point: he did not consider it a loss that the Constitution was not known among the general public, as it was generally of very little avail to them. See Kortman 2008, p. 15.
} 
Constitution. The absence of a constitutional court, and the political and pragmatic nature of constitutional review by the Advisory Council of State, stand in the way of developing a thorough and sophisticated discourse, and of developing a Dogmatik comparable to for instance the German, Italian or Spanish debates, which are heavily affected by the close relationship between the academic community and the constitutional court. ${ }^{13}$

\subsection{The Amendment of the Constitution in Relation to the European Union}

1.2.1 The European Union and Dutch membership do not feature in the text of the Constitution. Nevertheless, the Dutch Constitution has been revised once in the light of European integration. In 1953, in light of the then recently established European Coal and Steel Community (ECSC) and the planned European Defence Community (EDC), and with a view to further European integration, the chapter on foreign relations was adapted. It opens with a provision proclaiming that ' $[\mathrm{t}] \mathrm{he}$ government shall promote the development of the international legal order' (Art. 90). In order to make it clear beyond doubt that it is constitutional for powers to be transferred, Art. 67 (now Art. 92) declares that legislative, executive and judicial powers can be transferred to international institutions pursuant to a treaty. In addition, and again with a view to ensuring the smooth participation of the Netherlands in the international legal order generally and European integration specifically, the famous Arts. 65 and 66 were adopted. These provisions, now numbered Arts. 93 and 94 of the Constitution, provide for the direct effect of treaty provisions that are 'binding on anyone' and have duly been published, and award them primacy over conflicting provisions of national law.

The practical effect of these early amendments to date is that there is a high level of fit between European law and the Dutch constitutional environment. While Dutch judges may for a while have struggled with the concept of direct effect and were reluctant - given the traditional inviolability of primary legislation - to actually set aside national law in favour of international treaties and European law, adoption of the case law of the European Court of Justice (ECJ) on direct effect and primacy of EU law was rather smooth in the Netherlands.

1.2.2 In terms of the amendment procedure, the Constitution is rigid. The procedure for constitutional amendment is cumbersome and lengthy. It requires the approval by two consecutive parliaments with elections in between, and approval by a two-thirds majority in both Houses the second time. Twenty-three amendments have been passed between 1814 and 2008, that of 2008 being the last one to date, but several have been rather marginal.

${ }^{13}$ For a striking analysis of the situation in Germany, see e.g. Möllers 2011, pp. 283-408. 
1.2.3-1.2.4 The consecutive amendments of the European Treaties have never given rise to constitutional amendment. When the Maastricht Treaty was being adopted, there was some debate among constitutional lawyers on whether approval of that Treaty required the procedure in Art. 91(3) of the Constitution. If a transfer of powers conflicts with the Constitution or would lead to such conflicts, approval of such transfer requires a two-thirds majority in both Houses of Parliament (Art. 91 (3) of the Constitution). ${ }^{14}$ Thus, the fact that a Treaty tabled for approval conflicts with the Constitution does not mean that it cannot be approved and ratified: it merely means that approval requires a two-thirds majority in both Houses. This comes close to what is required to amend the Constitution, but is less demanding, as it does not require approval by two consecutive parliaments and elections in between. Moreover, the approval with a two-thirds majority does not formally amount to an amendment of the Constitution. Since Treaties take precedence over the Constitution in any case, such amendment would not be necessary.

The procedure has never been followed for approval of the EU Treaties, which were thus never considered to conflict with the Constitution. ${ }^{15}$ The provision has been interpreted as requiring a special majority only in cases of direct conflict between a provision of a Treaty and a specific provision of the Constitution. In other words, a tension with the spirit of the Constitution or principles and values underlying it is not considered sufficient to require special treatment. There was some discussion when the Treaty of Maastricht was tabled for approval, but the Government insisted that there was no conflict between the Treaty and the Constitution, and proceeded to ask Parliament for its approval in accordance with the ordinary procedure, i.e. by way of an ordinary Act of Parliament. ${ }^{16}$ The Treaty Establishing the European Stability Mechanism (ESM Treaty) and the Treaty on Stability, Coordination and Governance in the Economic and Monetary Union (Fiscal Compact) have also been approved as normal treaties by an ordinary Act of Parliament, and with strong support in Parliament. The Fiscal Compact did not give

\footnotetext{
${ }^{14}$ The decision as to whether the special procedure must be followed is made by a simple majority in both Houses.

${ }^{15}$ The only European treaty that was approved with a two-thirds majority in application of (what is now) Sect. 91, para. 3 of the Constitution, was the unsuccessful Treaty establishing the European Defence Community in 1954. Outside the context of the EU, the provision has been explicitly applied only twice: concerning the Act approving the Agreement Concerning West New Guinea (Stb. 1962, 363), and concerning the Act approving the Statute of the International Criminal Court (Stb. 2001, 343). For a critical examination of the practice and related procedural conundrums, see Besselink 2003, pp. 471-480 and Besselink 2002-2003.

${ }^{16}$ Heringa 1992, pp. 749-866. Heringa pointed to the provisions on EMU, which he considered to be at odds with Art. 106 of the Constitution which provided (and still does): 'The monetary system shall be regulated by Act of Parliament' and the provisions on visa policy and electoral rights for EU citizens. In all cases, the Constitution endows a task to the Dutch legislature. Most scholars did not agree with Heringa's views, and neither did the Government. More recently, questions have been raised about whether the extension of EU economic governance can be reconciled with Art. 105 of the Constitution, which allocates budgetary power to the Government and Parliament acting jointly.
} 
rise to constitutional amendment, notwithstanding its requirement in Art. 3(2) to introduce a balanced budget rule through 'provisions of binding force and permanent character, preferably constitutional, or otherwise guaranteed to be fully respected and adhered to throughout the national budgetary processes'. Because the budget is adopted by an Act of Parliament of the same rank as any other Act of Parliament, this could, strictly speaking, only be achieved by incorporating such a rule in the Grondwet. It was, however, implemented in primary legislation, the Wet HOF (the Sustainable Public Finances Act - 'Wet Houdbare Overheidsfinanciën').

The idea has been floated to make further steps in the process of European integration dependent on a stricter procedure and enhanced democratic legitimacy. One such proposal aims at amending the Constitution to require a two-thirds majority for the approval of all EU Treaties (amending treaties and accession treaties) as well as decisions to proceed to simplified revision. ${ }^{17}$ It has been approved in a first reading by the Lower House and is pending in the Upper House at the time of writing (June 2016).

More recently, in the wake of David Cameron's referendum promise to the British people, Burgerforum EU, a private initiative, asked for a referendum in cases of further transfers of powers to the EU. The request was rejected in the Lower House, but a motion was passed asking a report of the Council of State on whether there is a competence creep and whether additional democratic guarantees could be introduced. The Council of State issued its report in the summer of 2014, and a parliamentary debate was held in the summer of 2015, when the Foreign Minister firmly rejected the idea of 'creeping competences'.

The entire Constitution continues to apply when the Government or other state organs act in the context of the European Union. ${ }^{18}$ These bodies cannot, for instance, infringe on their constitutional obligations when participating in the Council of Ministers or other organs in which they represent the state. The relationship between the Dutch Government and Parliament is governed by the usual rules, and the conventional principles of ministerial responsibility and the duty to inform Parliament and so forth continue to apply. Government-Parliament relations are the same in the context of EU decision-making as they are in purely national matters.

Provisions of the Constitution that seem to be at least incomplete in the context of membership are simply read in the light of EU law and are further specified in

\footnotetext{
${ }^{17}$ Voorstel van rijkswet van de leden Herben en Van der Staaij houdende verklaring dat er grond bestaat een voorstel in overweging te nemen tot verandering in de Grondwet, strekkende tot invoering van het vereiste van een meerderheid van twee derden van het aantal uitgebrachte stemmen in de Staten-Generaal voor de goedkeuring van verdragen betreffende de Europese Unie (Bill of the members Herben and Van der Staaij with a view to declare that there is reason to consider the amendment of the Constitution, to the effect that a requirement of a two-thirds majority for the approval of treaties concerning the European Union), 30874 (R 1818). The private members' bill was introduced on 22 November 2006 and adopted in the Lower House on 22 September 2015 .

${ }^{18}$ See the report of the Royal Committee on the Constitution, Rapport Staatscommissie Grondwet 2010, pp. 105-106.
} 
ordinary law. Thus, for instance, Art. 3 of the Constitution stating that '[a]ll Dutch nationals shall be equally eligible for appointment to public service' is read as applying also, where relevant and with the exceptions allowed under EU law, to EU citizens. Article 4 which provides that '[e]very Dutch national shall have an equal right to elect the members of the general representative bodies and to stand for election as a member of those bodies, subject to the limitations and exceptions prescribed by Act of Parliament' is not considered to infringe EU law, as it does not say that the same does not apply, in particular cases, to EU citizens.

\subsection{Conceptualising Sovereignty and the Limits to the Transfer of Powers}

1.3.1-1.3.2 The Constitution has never been considered an obstacle to accession to the European Communities, the amendment of the European Treaties or to the domestic effect of European law. The concept of 'sovereignty', whether external or internal, popular or national, does not play a key role in the constitutional discourse. It is absent from the text of the Constitution. The idea that all public authority derives from the people or the nation as the ultimate holder of those powers has been virtually absent from the Dutch constitutional discourse: one tries to do without, both in theory and in constitutional practice. In many ways the very recent surge of 'sovereignty' in certain political circles and to some extent in academia is relatively novel.

The explanation for the overall lack of importance of sovereignty is historical. It has a long tradition that goes back at least as far as the Republic of the United Provinces, the political confederacy that was the result of the revolt against the ruling Spanish overlord, Philip II, and lasted from 1579 to 1795 . Within this confederal state, sovereignty was not located at the federal level, but in the provinces that composed it. This state of affairs was not intentional in as much as initially a search was undertaken to find a replacement for the abjured sovereign, but no suitable foreign prince who would be sufficiently pliable to the wishes of the provincial and local (particularly the cities of Amsterdam and Rotterdam) authorities could be found. Consequently, the republic ended up doing without a sovereign at national level and instead worked on the basis of consensus among the allegedly sovereign provinces. Seeking consensus instead of asserting sovereignty became part of the political DNA of the Netherlands' political culture. And to this day, we are faced with a state and a Constitution that leave the notion of sovereignty, if at all existent, at most implicit.

1.3.3 The issue of limits to participation in European integration is a political question rather than a legal constitutional one. Sovereignty being largely absent from the legal doctrinal debate, both in the context of European integration and more generally, the question of ultimate authority and the source of all state power is left undecided. 
This has made for a very smooth adaptation to EU membership, since no core principles, no inalienable principles or values require protection against the majority of the day or against the outside world. The controlimiti developed in other Member States are not developed in Netherlands constitutional doctrine. There is no Solange case law, if only because constitutional rights are less enforceable than EU law and fundamental rights. EU law was thus never considered a threat to national constitutional rights. No Dutch court has ever claimed jurisdiction to review the validity or applicability of EU law, or developed a theory of ultra vires acts; no court has ever formulated a view on 'national identity' or 'constitutional identity review'.

This all sits well with Dutch consociationalism and corporatism and the socially embedded patterns of democracy that have prevailed in the Netherlands, which to a large extent result from the perception of being a country of permanent minorities. Indeed, in terms of religious denomination the Netherlands was a country of permanent religious minorities for centuries, guaranteed by freedom of (religious) conscience, although it is also true that overall there was a dominant role for the Dutch Reformed Church, with periods of greater and lesser toleration of other Christian and of non-Christian religions. ${ }^{19}$ These realities forced a culture of consociationalism, toleration and pragmatic consensualism, which may now be under pressure after secularisation has created a new situation of a large majority of public agnosticism, which is more and more frequently framed - also by liberals as standing in opposition against a threatening minority of migrant aliens of Muslim faith. $^{20}$

Consociationalism and socially deeply-embedded democracy contributed to a constitutional culture where sovereignty claims were avoided, and that proved fertile soil for the reception of European law. Also, the theory of constitutional pluralism sits well with Dutch constitutional theory: European constitutional pluralism could be only a new, transnational guise of a broader pluralism, which was perhaps most elaborately theorised politically and philosophically as 'soevereiniteit in eigen kring', sovereignty within one's own sphere. This idea was developed in Calvinist circles, initially by Kuyper in the late 19th century ${ }^{21}$ and in a more profound philosophical sense by Herman Dooyeweerd ${ }^{22}$ as a counterpart of Catholic doctrines of 'subsidiarity' and the social-democratic theory of 'functional

\footnotetext{
${ }^{19}$ Freedom of religion was guaranteed as freedom of conscience in Art. XIII of the Union of Utrecht of 1579, which became the constitutional charter of the Republic. This did not encompass freedom to profess or manifest religion publicly, which was subject to restrictions of public order. Thus, Jews, Catholics, Lutherans and dissident protestants such as the Anabaptists were tolerated but could not openly profess their faith in all the provinces and cities. For Catholics there was a constitutional prohibition between 1848 and 1987 to hold religious processions in places where they had not customarily been held in 1848 (Art. 167, Grondwet 1848).

${ }^{20}$ Issues of racism that were previously reigned in come out in the open; in a recent opinion poll nearly two-thirds of respondents found that ethnic profiling by the police is acceptable in the fight against crime, and less than one-third consider it a form of racism; see https://www.noties.nl/v/get. php?a=peil.nl\&s=weekpoll\&f=2016-06-05b.pdf.

${ }^{21}$ Kuyper 1880.

${ }^{22}$ Dooyeweerd 1984.
} 
decentralisation' (note that, by the second half of the 19th century, these social groups of the various religious denominations, 'neutrals' and socialists became strongly organised in what were later called 'pillars', each having their own churches and meeting halls, sports clubs, cultural and literary clubs, insurance companies, newspapers, radio and television broadcasting, trade unions, political parties and political doctrines and theories).

In the present situation in which important social determinants of the old constitutional culture have eroded, however, in political circles, in academia and in government circles the question has been raised whether the Dutch legal order should continue to be so open towards the European Union, and whether the Constitution could not or should not provide a bulwark against the incoming tide of European law. A symptom of this was that the Netherlands was one of the Member States to reject and thereby cause the defeat of the Constitutional Treaty, and is no longer all that Europhile.

The Constitution does not specify conditions for the conferral of powers to international institutions, nor does it indicate explicit limits to such conferral. Neither does it contain an immutable core that cannot be transferred. The Dutch Constitution remains agnostic towards fundamental questions of European integration that have arisen elsewhere. In line with the historic absence of a legal sovereignty debate, constitutional doctrine is rather pragmatic. Thus it would seem that at the end of the day, the Netherlands can commit 'constitutional harakiri' or at least, there are no legal constitutional obstacles prohibiting the transfer of powers that elsewhere are labelled as essential state functions or the core of the constitution.

Over time, some limits have been suggested, but these have been few and far between. Until 1983 the provision that allows for the approval of treaties that diverge from the Constitution by qualified majority in Parliament, now Art. 91(3) Grondwet, allowed such divergence 'if the development of the international legal order so requires'. These quoted words - which suggest a condition and possibly a limit to transfer of powers - were dropped in 1983 as 'superfluous'. ${ }^{23}$ The provision was considered to be essentially procedural in nature, not one to determine when a treaty diverges from the Constitution. Although it was conceded that the language did provide a touchstone, preference was given to no such clause over 'vague, shifting and incomplete criteria', all the more since the need to diverge by treaty from the Constitution could possibly be dependent on considerations that are quite different from the 'development of the international legal order'. ${ }^{24}$

When in 1953 the possibility was created to diverge by treaty from the Constitution, the Government expressed the view that such divergence only exists when there is a divergence from a concrete provision, ${ }^{25}$ but it also conceded in response to two members of the Lower House, that the Kingdom could not become a party to a treaty if that would amount to giving up the 'foundations or essentials of

\footnotetext{
${ }^{23}$ Parliamentary documents, Tweede Kamer 1977-1978, 15049 (R 1100), No. 3, p. 5.

${ }^{24}$ Parliamentary documents, Tweede Kamer 1979-1980, 15049 (R 1100), No. 10, pp. 7-8.

${ }^{25}$ Handelingen Eerste Kamer [Proceedings of the Upper House], 1952-1953, pp. 480 and 484.
} 
the national legal order, for instance the monarchical-parliamentary system, even to the extent that these are not incorporated in the Constitution [Grondwet]' for the sake of the development of the international legal order. ${ }^{26}$ These two, seemingly incompatible positions can be reconciled by distinguishing on the one hand the divergence from specific and concrete provisions as the legal constitutional standard for determining the application of the requirement of a qualified majority from, on the other hand, the existence of treaties to which the Kingdom could not become a party even with the qualified majority provided for in Art. 91(3) of the Constitution by the standards of political propriety and acceptability.

Much later, in November 1999, the Council of State (Raad van State) gave an advisory opinion on the implementation acts concerning foreign jurisdictions in the Netherlands (the Scottish Lockerbie court), in which it suggested that the Kingdom could not become a party, not even under the procedure in Art. 91(3) of the Constitution, to treaties that conflict with 'essential constitutional guarantees, especially the fundamental rights of chapter 1 of the Constitution', if 'the conflict with fundamental rights is so fundamental as to make ratification of such treaties unacceptable'; also, it found that the EU Treaties and the European Convention on Human Rights could be an obstacle to ratification. ${ }^{27}$ Although the Netherlands Council of State has begun to think of itself as a kind of constitutional council, these points can be considered a political assessment in light of the matter at hand, rather than an authoritative constitutional interpretation, guiding the constitutionality of transfers of sovereign powers. This is evident from the predominant assertions that always accompany these same interventions, which insist that divergences between a treaty and the Constitution only exist when a treaty conflicts with concrete provisions of the Constitution, not when sovereignty transfers as such are concerned. This was evident in the Council's advisory opinion on cruise missiles of 23 December 1983, in which it made clear that a mere limitation, infringement or transfer of sovereignty is as such not in conflict with the Constitution, ${ }^{28}$ that the question how far a transfer could go was not a matter of constitutional law but a political assessment, ${ }^{29}$ and that a discrepancy with one or more specific provisions of the Constitution is required for there to be a conflict with the Constitution. ${ }^{30}$

All this should not be taken to mean that there is no debate on the limits of European integration: 'sovereignty' is now hotly debated, and is key to the Eurosceptic discourse. Both the ECHR and the EU are described as threats to Dutch sovereignty. But the concept is not used in the legal debate, and as such, the consequences of European integration for Dutch sovereignty (however conceived) are under-theorised. It could even be said that constitutional law and constitutional

\footnotetext{
26 Ibid., p. 480, left column.

27 Advisory Opinion, Raad van State, 19 November 1999, Parliamentary documents, Tweede Kamer 1999-2000, 26800 VI A, p. 6.

${ }^{28}$ Parliamentary documents, Tweede Kamer 1983-1984, 17 980, A, p. 2, middle column.

29 Ibid., p. 4, left column.

${ }^{30}$ Ibid., p. 3, left column.
} 
theory have not been able to offer a framework to conceptualise the participation of the Netherlands in European integration.

1.3.4 The acceptance of primacy The primacy of EU law is not phrased in terms of sovereignty or the conferral of powers to the EU. The majority of constitutional lawyers, joined by the criminal chamber of the Hoge Raad, do not even consider the primacy of EU as deriving from the Constitution but from EU law autonomously. The constitutional provisions, which are perfectly apt to sanction the doctrines of direct effect and primacy as they have been developed by the ECJ, are not seen to regulate the domestic effect of EU law. Predominantly, scholars and courts distinguish between the direct effect and primacy of international treaties (deriving from the Constitution) and the direct effect and primacy of EU law (deriving from the very nature of EU law as set out by the Court of Justice in Van Gend en Loos ${ }^{31}$ and Costa v. ENEL ${ }^{32}$ ).

Fundamental issues of European integration, or major steps in the process, which have given rise to constitutional case law elsewhere, such as the Maastricht Treaty, the Lisbon Treaty or the European Arrest Warrant (EAW), have never been decided by the courts. These are considered political issues which are not for the courts to decide.

\subsection{Democratic Control}

1.4.1 Ever since the adoption of the EEC Treaty in 1957, democracy - and more particularly parliamentary representation of citizens - has been a matter of great concern within the Dutch Parliament, the States General (Staten-Generaal). What was later referred to as the 'democratic deficit' was identified in the parliamentary debates already at the time the EEC Treaty was approved in 1957: the limitation of democratic representation at national level was not accompanied by parliamentary representation at the European level. ${ }^{33}$ It is still a key concern in parliamentary debates with every amendment of the founding treaties. This also implies that right from the beginning, and at least until the moment a strong parliament had been established at European level, the role of the national parliament was viewed as part of an overall European political system.

One of the particularities of the debate in the Netherlands is the importance attributed to the European Parliament: its lack of formal powers of co-decision has been a major justification for a role for the national parliament, and its possession of

\footnotetext{
${ }^{31}$ C-26/62 Van Gend en Loos v. Administratie der Belastingen [1963] ECR 00003.

${ }^{32}$ C-6/64 Costa v. E.N.E.L. [1964] ECR 01141.

${ }^{33}$ At the time, this may have been inspired by similar concerns expressed in the Bundestag. The proposals for a resolution of the Bundestag were included in the parliamentary documents of the States General, see Bijlagen Handelingen TK [Parliamentary Documents Lower House] 19561957, 4725, No. 14.
} 
co-decisive powers as a justification to tone down that role. Nevertheless, the Dutch Parliament has always been active in scrutinising European affairs, at least in certain policy sectors. In the Act on Approval of the EEC and Euratom Treaties of 1957, it was stipulated that the Government was to send Parliament an annual overview of the development of European integration. This is the legal basis for an annual debate on European integration, since 1999, called 'the State of the Union debate' in which Dutch Members of the European Parliament (MEPs) participate. $^{34}$ Possibly the very first national parliamentary Resolution on guaranteeing the role of a national parliament was adopted by the Netherlands Lower House (Tweede Kamer) on 11 January 1967:

The House, ... judges that the Netherlands Government shall not agree to definitive decisions in the Council on Community measures concerning the size and distribution of the tax burden unless it has previously consulted the Netherlands Parliament. ${ }^{35}$

A similar veto right was introduced in the acts approving the Schengen Convention, the Maastricht Treaty, and repeated in the acts approving the Nice and Amsterdam treaties, as regards binding EU decisions on justice and home affairs. These were largely abolished on the approval of the Lisbon Treaty with the justification that those decisions were at that time within the powers of the European Parliament as a co-legislator. This shows the old concern for democratic parliamentary representation at the European level as adequate compensation for diminished democratic legitimacy at the national level. On a critical note, one must wonder whether that can fully be the case, in as much as the European Parliament (EP) cannot hold individual members of the Council or European Council to account; the Netherlands Parliament could, however, effectively sanction a minister or the prime minister for positions taken there. The assumption that accountability towards the EP is sufficient could give rise to the misunderstanding that the Dutch members of the Council and European Council are not accountable to the national parliament. ${ }^{36}$ The pernicious effect of the Dutch approach to the democratic deficit could lead to ministers taking even less responsibility for what they agree or failed to agree to in Brussels than the low level of responsibility they are currently prepared to carry, and towards an increasingly EU-critical public opinion. ${ }^{37}$

\footnotetext{
${ }^{34}$ The idea of an annual report may have been inspired by a similar undated resolution of the French Assemblée, reproduced in the Lower House parliamentary documents: 'a. Le Gouvernement devra presenter annuellement au Parlement, en vue de son approbation, un compte rendu de l'application du Traite de Communauté Economique Européenne et des mesures économiques fiscales et sociales intervenues dans la Communauté, en exposant les mesures qu'il a prises ou qu'il entend prendre pour faciliter 1'adaptation des activités nationales aux nouvelles conditions du Marché.'

${ }^{35}$ Motie (Resolution) introduced by MPs Berg c.s. 11 January 1967. Bijlage Handelingen Tweede Kamer (Appendix to the Minutes of the Lower House), 1966-1967, 8556, No. 8.

${ }^{36}$ For an analysis of the influence on parliamentary scrutiny after the abolition of the parliamentary veto right, see Besselink 2012a.

${ }^{37}$ Eijsbouts 2014, pp. 13-15.
} 
1.4.2 When the Treaty establishing a Constitution for Europe was up for approval and several Member States decided to hold a referendum on it, the Dutch Government followed suit at the request of three pro-European Members of Parliament. The Constitution does not provide for referendums, but it does not forbid them either, as long as they are advisory only. ${ }^{38}$ Although between 2002 and 2005 there was a Temporary Referendum Act containing general rules for advisory corrective referendums, no national referendum had been held in the Netherlands for nearly 200 years. There was, thus, no experience with the instrument when the referendum on the Constitutional Treaty was held on the basis of a separate Referendum Act in June 2005.

Asked for advice about the referendum, the Council of State stated - in a fairly sober and balanced opinion - that given the character of the Treaty, its ratification could to a certain extent be compared to an amendment of the Constitution, and a referendum would offer a realistic means to involve voters. When the Dutch people voted the Constitutional Treaty down and the Lisbon Treaty was up for ratification, that opinion would haunt the Council. The Government consulted the Council again, asking whether approval of the Lisbon Treaty would require a referendum, given that it largely resembled the Constitutional Treaty. This time, the Council of State opined that the Lisbon Treaty, in view of its contents, method and ambition, fitted in the existent process and that the changes made after the referendum (abandoning the concept of one written constitutional document, the deletion of the Charter from the body of the Treaty, the clearer demarcation of the competences of the Union and the omission of the symbols of European unification) had to be seen as a whole, and justified the choice for a 'normal' approval by way of an ordinary Act of Parliament and for not holding a referendum. ${ }^{39}$

Among ideas to make further European integration dependent on more strictly democratic procedures, we already mentioned the bill introducing a qualified majority of two-thirds of the vote and the request for referendums that was rejected in the Lower House (see Sects. 1.2.3-1.2.4 above).

In the meantime, the same private initiative that requested referendums for further transfers of powers managed to collect 300,000 signatures to require a referendum on the Act approving the Association Agreement with Ukraine under the new Consultative Referendum Act $2014 .{ }^{40}$ The promoters of the referendum acknowledged that the Act might not be the best subject for an EU referendum, but they considered it the only feasible manner to have the European project put before

\footnotetext{
${ }^{38}$ A binding referendum is unconstitutional, since the power to create Acts of Parliament - and therefore the power to approve treaties - is vested explicitly in the legislature: the Government and Parliament jointly, in accordance with the procedure laid down in Arts. 81-88 of the Constitution. ${ }^{39}$ Advisory Opinion of the Council of State, 15 February 2008, W01.08.0004/I/K, Kamerstukken II 2007/08, 31384 (R 1850), No. 4.

${ }^{40}$ Wet van 30 september 2014, houdende regels inzake het raadgevend referendum (Wet raadgevend referendum).
} 
the people. The attempt of a citizen to ask the Council of State for an injunction against the referendum was declared inadmissible for lack of personal interest. ${ }^{41}$ In the referendum, $61 \%$ of voters voted against the Act, with a turnout of $32 \%$ - the 'no' vote comprising less than $20 \%$ of the electorate (which is slightly lower in proportion to the Members of Parliament who voted against the approval of the Association Agreement). ${ }^{42}$ The result is not binding, but the Government must reconsider. The Prime Minister announced that the Association Agreement would not be ratified 'unconditionally', but postponed any decisions until after the Dutch EU presidency in the first half of 2016. In the meantime, the Netherlands Government negotiated a decision of 15 December 2016 of the European Council, mainly of an interpretative nature, to the Association Agreement, which was subsequently approved by Parliament. ${ }^{43}$ The Consultative Referendum Act was revoked in 2018.

\subsection{The Reasons for, and the Role of, EU Amendments}

1.5.1 Not applicable.

\subsection{2}

(a) The Constitution has not been amended thus far, for several reasons. First and foremost, the constitutional framework is considered sufficient to support participation in the European Union. There is, thus, no perceived need for constitutional amendment. Secondly, constitutional amendment is tedious and difficult, and politicians seek to avoid it when they can. Thirdly, the political elite may well prefer the current flexibility towards European integration and would prefer not to make it more difficult for the state to make a political decision to participate in further steps in European integration. In the Dutch constitutional culture, this type of decision is considered first and foremost a political decision, which should not be in the hands of lawyers and courts, but of politicians, i.e. the representatives of the people in Parliament, as well as the Government.

(b) There is no widely shared feeling among constitutional scholars that the European deficit in the Dutch Constitution threatens the societal relevance of the Constitution. In fact, there is a widely shared consensus among constitutional lawyers that the relevance of the Constitution is limited generally, because of the

\footnotetext{
${ }^{41}$ Afdeling bestuursrechtspraak (Raad van State), decision of 26 October 2015, ECLI:NL: RVS:2015:3399.

${ }^{42}$ Under the Act, the outcome of the referendum is valid if $30 \%$ of voters turn out. The outcome is not binding, but it appears politically difficult to ignore the clear majority of the vote, even though the no-vote represents only a small minority of the electorate.

${ }^{43}$ See European Council Conclusions, Brussels, 15 December 2016, EUCO 34/16, Annex.
} 
absence of constitutional review, and the particular structure of the fundamental chapter in the Constitution that generally allows the legislature to restrict the rights the Constitution grants to individuals. So on the whole, there is not a general feeling of 'waning constitutionalism' as a consequence of European integration.

1.5.3 In line with the recommendations of a majority of the 2009-2010 Constitutional Committee, the authors of this report are in favour of introducing the requirement of a qualified majority of two-thirds of the vote in Parliament for the approval of treaties that have a major influence on the functioning of the constitutional order of the Netherlands - this would typically apply to the amendment of the founding Treaties of the European Union. We support the view of half of the members of that Committee that it is desirable to subject the application of international decision-making to the minimum requirements of a democratic state under the rule of law, as the Committee proposed to introduce in a new first article of the Constitution (see above Sect. 1.1). This we perceive not as a brake on European integration or on international cooperation, but as both mirroring and actively contributing to the substantive constitutionalisation of the European and international legal orders.

\section{Constitutional Rights, the Rule of Law and EU Law}

\subsection{The Position of Constitutional Rights and the Rule of Law in the Constitution}

2.1.1 Fundamental rights are contained in the first chapter of the Constitution. General principles, such as legal certainty and proportionality, are not as such mentioned in the text of the Constitution. Constitutional rights do not, however, offer strong protection against the primary legislature. The Constitution proclaims rights, but then often allows the primary legislature to limit these rights, without, however, carving out the precise conditions for such limitations. ${ }^{44}$ Moreover, constitutional rights are not justiciable in such cases, given the absence of judicial review of Acts of Parliament against the provisions of the Constitution. International conventions, such as the ECHR, the ICCPR and the EU Charter are better enforceable than rights contained in the Constitution. As a consequence, the Constitution is also often considered to be less meaningful in the political process than human rights treaties, more specifically the ECHR.

2.1.2 There is no general limitation clause in the Constitution, and the specific provisions containing rights offer the legislature significant leeway to restrict rights.

\footnotetext{
${ }^{44}$ By way of example: Art. 8 reads: 'The right of association is recognized. This right may be restricted by Act of Parliament in the interest of public order.'
} 
2.1.3 The principle of 'rechtsstatelijkheid' (rule of law) is not laid down in the text of the Constitution, but is considered a general principle of law. Several elements of the rule of law are included in the constitutional text, such as the right to be heard (Art. 17 Constitution). The case law in this matter, however, is mainly built on Art. 6 ECHR.

\subsection{The Balancing of Fundamental Rights and Economic Freedoms in EU Law}

2.2.1 Given the limited legal effectiveness of constitutional rights, EU law is hardly considered a threat to those rights in general. It has been argued, however, that EU law does contain a bias in favour of free movement over fundamental rights, ${ }^{45}$ while others have argued that EU law offers sufficient ways to balance fundamental rights and economic freedoms, and that there is no bias for one over the other. ${ }^{46}$ Some authors have argued that the advent of the binding EU Charter increases fundamental rights protection in the Netherlands, given the procedural advantages of EU law over ECHR law. ${ }^{47}$

\subsection{Constitutional Rights, the European Arrest Warrant and EU Criminal Law}

Overview of the national implementation of the EAW and the human rights clause The EAW was implemented in Dutch legislation in the Overleveringswet 2004 (OLW). ${ }^{48,49}$

This Act contains a number of provisions that seem to add fundamental rights guarantees over and above what the Framework Decision ${ }^{50}$ provides for.

First, Art. 11 of the OLW provides for a general fundamental rights exception if the court has sufficient grounds founded in facts and circumstances to suspect a 'flagrant breach' of the ECHR. ${ }^{51}$ It does not mention Art. 6 TEU or the EU Charter

\footnotetext{
45 John Morijn 2006.

${ }^{46}$ Sybe de Vries 2016.

${ }^{47}$ Morijn et al. 2015.

${ }^{48}$ The authors are grateful for very significant preparatory research on this question by Xanthe Born.

${ }^{49}$ Law on the surrender of persons (Overleveringswet), Stb. 2004, 195, 11 May 2004.

${ }^{50}$ Council Framework Decision of 13 June 2002 on the European arrest warrant and the surrender procedures between Member States (2002/584/JHA), [2002] OJ L 190/1.

51 'Overlevering wordt niet toegestaan in gevallen, waarin naar het oordeel van de rechtbank een op feiten en omstandigheden gebaseerd gegrond vermoeden bestaat, dat inwilliging van het
} 
which are explicitly mentioned in Art. 1(3) of the Framework Decision. The provision is extremely restrictive, as it is reserved to cases of suspicion of 'flagrant breach' of the ECHR. Both elements are remarkable: in the implementation of EU law, EU fundamental rights - mainly the EU Charter - are primary, rather than the ECHR, even if the latter provides the minimum level of protection and defines the interpretation of the Charter (Art. 52(3) Charter). The restriction to cases of 'flagrant' breaches offers less protection than the ECHR, as the European Court of Human Rights (ECtHR) does not impose such a high threshold in cases of violations of Art. 3 ECHR. As such, this restriction would also infringe the duty contained in the Charter to respect the minimum level of protection contained in the ECHR (Arts. 52(3) and 53 Charter). The Dutch court that is competent to hear EAW cases as a court of sole instance from which no appeal is possible, the District Court of Amsterdam, has solved this problem to some extent by qualifying a breach of Art. 3 ECHR as 'flagrant' in itself. ${ }^{52}$ Yet, arguments based on unfair trial have not been very successful in the Netherlands, and the courts have typically made reference to Jeremy $F^{53}$ and the ECtHR. Whenever a court had doubts about the prison conditions in the requesting Member State, after the judgment of the ECtHR in Varga $^{54}$ and in view of the pending reference by the Hanseatisches Oberlandesgericht in Bremen to the Court of Justice of the European Union in Aranyosi, ${ }^{55}$ the court would suspend all pending cases concerning delivery to Hungary. ${ }^{56}$ Below we discuss how courts have acted subsequent to Aranyosi (Sect. 2.3.1 in fine).

verzoek zou leiden tot flagrante schending van de fundamentele rechten van de betrokken persoon, zoals die worden gewaarborgd door het op 4 november 1950 te Rome tot stand gekomen Europees Verdrag tot bescherming van de rechten van de mens en de fundamentele vrijheden.' (Surrender shall not be allowed in cases where, in the opinion of the court, there is justified suspicion, based on facts and circumstances, that granting the request would lead to flagrant breach of fundamental rights of the person concerned, as guaranteed by the [ECHR]).

52 Rb. Amsterdam, 22 October 2010, ECLI:NL:RBAMS:2010:BO1448.

${ }^{53}$ Case C-168/13 PPU F. [2013] ECLI:EU:C:2013:358.

${ }^{54}$ ECtHR, 10 March 2015, Varga and Others v. Hungary, Nos. 14097/12, 45135/12, 73712/12, $34001 / 13,44055 / 13$ and 64586/13.

55 Joined cases C-404/15 and C-659/15 PPU Aranyosi and Căldăraru [2016] ECLI:EU: C:2016:198.

${ }^{56}$ See Rb. Amsterdam, 17 November 2015, ECLI:NL:RBAMS:2015:7977 and press release by the District Court of Amsterdam, 31 December 2015, https://www.rechtspraak.n1/Organisatie-encontact/Organisatie/Rechtbanken/Rechtbank-Amsterdam/Nieuws/Paginas/Schendingmensenrechten-in-Hongaarse-gevangenissen.aspx. 


\subsubsection{The Presumption of Innocence}

2.3.1.1-2.3.1.2 To the chagrin of the European Commission, ${ }^{57}$ a defence of innocence is provided for in the Overleveringswet as an additional ground for refusal beyond those mentioned in the Framework Decision. The District Court has to refuse surrender if it is impossible that a suspicion of guilt can apply to the requested person with regard to the facts for which his surrender is requested (Art. 28(3) OLW). The District Court of Amsterdam must examine the claim of innocence of the requested person, which must be made prior to the hearing and supported with evidence during the hearing (Art. 26(4) OLW).

Although there is abundant case law on the EAW combined with the presumption of innocence, in the published case law there are only two decisions in which reliance on this principle has provided grounds to refuse surrender. The judicial assumption is that it is for the issuing state to assess such appeals, as they have full knowledge of the case file. Exemplary is the case of 25 April $2008^{58}$ in which the Court stated that reliance on the presumption of innocence in the sense of Art. 6 ECHR is irrelevant in surrender proceedings in the executing state and must be left to the issuing authority. This is remarkable, as Art. 26(4) OLW is explicit that the Court must examine any claim concerning the presumption of innocence.

Of the two cases in which reliance on the principle of innocence was successful, in one case the requested person was able to produce a hospital report showing that he was in treatment for viral hepatitis $\mathrm{A}$ and $\mathrm{B}$ at the time he was said to have committed criminal offences in Germany. The court considered this report sufficient to prove that he was innocent. ${ }^{59}$

In the other case, the requested person produced a document that proved he was preventively detained at the time some of the criminal offences were committed for which his surrender was requested, which led the Court to decide to refuse the EAW partially, that is to say for the offences for which the actual presence of the requested person during the commission of the criminal offences was necessary. His physical presence was not necessary for the commitment of the other offences and thus his surrender was allowed for those. ${ }^{60}$

Finally, it must be signalled that although the Netherlands' implementing legislation does not incorporate a proportionality test, the Court often reviews the

\footnotetext{
${ }^{57}$ Report from the Commission based on Art. 34 of the Council Framework Decision of 13 June 2002 on the European arrest warrant and the surrender procedures between Member States, Brussels: 23 February 2005, $\operatorname{COM}(2005) 63$ final, p. 8; criticism on the part of Dutch criminal lawyers has come amongst others from R. Malewicz 2006, p. 498, is shared by H. Sanders 2012, par. 6 and partly by V.H. Glerum 2013, p. 622. Sanders does not agree, however, with the Commission's assumption that the claim of innocence as a ground for refusal requires an examination in substance of the case; see Sanders 2011, pp. 119-120.

${ }^{58}$ ECLI:NL:RBAMS:2008:BD2475, District Court of Amsterdam, 25 April 2008, para. 9.

${ }^{59}$ ECLI:NL:RBAMS:2011:BR3388, District Court of Amsterdam, 27 July 2011.

${ }^{60}$ Ibid.
} 
proportionality of a surrender. ${ }^{61}$ It will not surrender when it is considered disproportionate. This arguably constitutes a further breach of EU law as it adds a further ground for refusal that is not provided for in the Framework Decision.

It must be noted that the Court distinguishes 'systemic proportionality', i.e. that powers of the OLW to surrender a person may not exceed what is necessary to realise the objectives of the Framework Decision, from the proportionality of a surrender in a concrete case in light of the particular circumstances. The latter form of proportionality review is justified by the Court under reference to a Council Recommendation that holds that

[c]onsidering the severe consequences of the execution of an EAW as regards restrictions on physical freedom and the free movement of the requested person, the competent authorities should, before deciding to issue a warrant, bear in mind, where possible, considerations of proportionality by weighing the usefulness of the EAW in the specific case against the measure to be applied and its consequences. ${ }^{62}$

It is only in the second type of proportionality review that an appeal has on rare occasions been successful. The criterion is that the surrender must be 'disproportionally burdensome' (onevenredig bezwarend). This has only succeeded in cases of very serious health situations that involve the certainty or high chance of death of the surrendered person. ${ }^{63}$

In November 2015, the Court of Amsterdam suspended the surrender of a suspect to Hungary, and asked the Hungarian requesting authorities for more information about the prison conditions. The court referred to the preliminary reference sent by the Hanseatisches Oberlandesgericht in the Aranyosi case, in which that court cited a European Committee for the Prevention of Torture (CPT) report and the case law of the ECtHR, and held that there were indications of infringements of Art. 3 ECHR. ${ }^{64}$ Since the decision of the ECJ in Aranyosi, the Amsterdam court has regularly applied it, and requested additional information on prison circumstances, or rejected claims that there was a real risk of inhuman or degrading treatment under Art. 4 Charter, for instance on the basis of additional

\footnotetext{
${ }^{61}$ Out of 911 published judgments on the European Arrest Warrant decided by the Amsterdam District Court up to June 2016, the combined search terms of 'Europees aanhoudingsbevel' and 'evenredigheid' yield 59 hits; the combination of the search terms 'Europees aanhoudingsbevel' and 'onevenredig bezwarend' ('disproportionally burdensome'), which is the criterion for proportionality in the individual case, leads to 34 hits.

${ }^{62}$ See District Court Amsterdam 30 December 2008, ECLI:NL:RBAMS:2008:BG9037, para. 6.3; the reference is to the Handbook on how to issue a European Arrest Warrant, 8216/1/08 REV 2 COPEN 70 EJN 26 EUROJUST 31, para. 3 'Criteria to apply when issuing an EAW - principle of proportionality', p. 14. http://www.consilium.europa.eu/ueDocs/cms_Data/docs/polju/EN/EJN757.pdf.

${ }^{63}$ Two cases are District Court Amsterdam 1 March 2013, ECLI:NL:RBAMS:2013:BZ3203, which is the standard to which later judgments refer, and District Court Amsterdam, 26 June 2012, ECLI:NL:RBAMS:2012:BY8250.

${ }^{64} \mathrm{Rb}$ Amsterdam 11 November 2015, ECLI:NL:RBAMS:2015:7977.
} 
information granted by the Romanian authorities, ${ }^{65}$ or on the basis of general information on prison conditions in Poland. ${ }^{66}$

\subsubsection{Nullum crimen sine lege praevia}

2.3.2.1 A study undertaken in 2010 indicated that until June 2010 in approximately a quarter of the cases, the courts undertook some form of dual criminality test. ${ }^{67}$ Since 1 June 2010 approximately 300 judicial authorities have assessed around 300 EAWs in which dual criminality played a role. A test whether the relevant offence is listed in the OLW (that is identical to that of the Framework Decision) suffices. Until 2008, the courts would request the legislation of the issuing state from the issuing authority in translation (in English), but the Hoge Raad (Dutch Supreme Court) criticised this as being in conflict with the principles underlying the Framework Decision. ${ }^{68}$ Since then, in cases of doubt, the courts will rely on the descriptions in the warrants and translate that into terms of Netherlands criminal offences, in order to assess whether the judicial authorities of the issuing state could reasonably have identified the offences as listed offences. But rarely has this been an obstacle to the surrender of the requested person. There are around 30 cases (out of slightly over 650) before the District Court of Amsterdam to be found where the requested person claimed that the listed offence and the facts as described in the EAW were in 'obvious conflict'. In three cases, this claim proved to be successful. $^{69}$

\subsubsection{Trial In Absentia}

2.3.3.1 The optional grounds for refusal in the revised Framework Decision of 2009 concerning trial in abstentia is implemented differently and turned into a mandatory ground for refusal in the OLW (Art. 12). In the literature, this is justified with reference to the Wolzenburg ${ }^{70}$ judgment of the Court of Justice, and it is pointed out

\footnotetext{
${ }^{65}$ Rb Amsterdam 2 May 2016, ECLI:NL:RBAMS:2016:2629 (Romania). The court considered the information granted by the Romanian authorities sufficient to decide that the prison conditions had been improved since the decisions of the ECtHR relating to the relevant prison.

${ }^{66}$ Rb Amsterdam 24 May 2016, ECLI:NL:RBAMS:2016:3081 (Poland). The court considered the evidence adduced (ECtHR decisions dating back to 2009 and 2010 and a CPT report of 2014) insufficient to qualify the general prison conditions in Poland as a real risk of inhuman and degrading treatment.

${ }^{67}$ Kurtovic and Langbroek 2010, p. 4.

${ }^{68}$ HR 8 July 2008, para. 3.5.2, ECLI:NL:HR:2008:BD2447.

${ }^{69}$ District Court of Amsterdam, 26 August 2011, para. 5, ECLI:NL:RBAMS:2011:BR7003; District Court of Amsterdam, 7 October 2011, para. 4, ECLI:NL:RBAMS:2011:BT7217; District Court of Amsterdam, 25 June 2013, para. 4.1, ECLI:NL:RBAMS:2013:3852.

${ }^{70}$ Case C-123/08 Dominic Wolzenburg [2009] ECR I-09621.
} 
that the implementing act does not broaden the cases in which surrender is to be refused. In the judgment of 16 June 2016 of the District Court of Amsterdam which followed up the judgment of the Court of Justice of 24 May 2016 in the case of Pawet Dworzecki ${ }^{71}$ that the district court had referred, it relied moreover on the written answer of the Netherlands Government to a question posed by the Court of Justice on the reasons for introducing this mandatory ground. The Government stated that the reason for this was 'the protection of the right to a fair trial and for reason of creating clear and transparent criteria for the judicial authorities to decide whether to refuse the execution of an EAW'. ${ }^{72}$ In Dworzecki, the issue concerned the question to what extent an executing judicial authority must ascertain whether the person tried in absentia had been informed of the trial, or must rely on an assessment by the issuing authority. Dworzecki and its follow-up clearly demonstrate how the principle of mutual recognition is subjected to restrictions informed by the right to a fair trial and the principle of legal certainty.

\subsection{The EU Data Retention Directive}

2.4.1 As was the case elsewhere, questions were also raised in the Netherlands about the usefulness and necessity of the Data Retention Directive. ${ }^{73}$ During the parliamentary proceedings leading to the adoption of the Data Retention Act 2009, the issue of privacy was heavily debated. ${ }^{74}$ The core issue was whether the Act would pass muster in the light of the right to privacy as protected under Art. 8 ECHR and Art. 10 of the Constitution. Given the fact that the Constitution does not contain a general reference framework for limitation (see above Sect. 2.1.1), the focus of attention was on Art. 8 ECHR. In the Upper House (the Dutch Senate), reference was made to the Vorratsdatenspeicherung decision ${ }^{75}$ of the German Federal Constitutional Court. In light of possible effects on privacy, in the end the choice was made for a retention period of one year for fixed and mobile telephony

\footnotetext{
${ }^{71}$ Case C-108/16 PPU Dworzecki [2016] ECLI:EU:C:2016:346.

72 District Court Amsterdam 16 June 2016, ECLI:NL:RBAMS:2016:3643, para. 5.4 in fine.

${ }^{73}$ Directive 2006/24/EC of the European Parliament and of the Council of 15 March 2006 on the retention of data generated or processed in connection with the provision of publicly available electronic communications services or of public communications networks and amending Directive 2002/58/EC, [2006] OJ L 105/54.

${ }^{74}$ On the background and application of the Dutch implementing Act, see G Odinot et al., The Dutch implementation of the Data Retention Directive. On the storage and use of telephone and internet traffic data for crime investigation purposes, Eleven International Publishing (2014); WODC Report 310a, (2014), available at https://www.wodc.nl/onderzoeksdatabase/ov-201402the-dutch-implementation-of-the-data-retention-directive.aspx (the WODC is the Research and Documentation Centre of the Ministry for Security and Justice and aims to make a professional contribution to development and evaluation of justice policy set by the Ministry).

${ }^{75}$ BVerfG, Urteil des Ersten Senats vom 02. März 2010 - 1 BvR 256/08 - Rn. (1-345), BVerfGE $125,260$.
} 
and six months for internet data (as opposed to 18 months in the original proposal and 12 months after the debate in the Lower House).

The Senate remained critical and kept an eye on European developments pertaining to data retention. For example, the Senate's objections to data retention were voiced in the permanent justice committee's report on the assessment of the Data Retention Directive. ${ }^{76}$ These concerns included a brief yet convincing analysis of the absence of pressing social need, and that not enough attention was being paid to the proportionality of the measure.

The Data Retention Act was never challenged in court, until the Court of Justice invalidated the Data Retention Directive in Digital Rights. ${ }^{77}$ In several criminal cases courts have rejected the argument that evidence used on the basis of data retained under the Act could not be used, since the EU Directive on which it was based had been declared invalid. The reason for this rejection is that it is not the Data Retention Act 2009 that allowed the use of that information, but the relevant provisions of the Code of Criminal Procedure. Moreover, the case law of the Hoge Raad is very restrictive in disallowing unlawfully procured evidence: the unlawfulness that resides in an infringement of the right to a fair trial is distinct from that of other fundamental rights, in the sense that an infringement of, for instance, the right to privacy must be shown also to amount to an infringement of the right to a fair trial, which is not necessarily so. ${ }^{78}$

A different case ended in the Tax Chamber of the Court of Appeal of 's-Hertogenbosch, on 27 March 2015, that found that the use of the data collected with police cameras for the purpose of uncovering tax fraud in relation to the private use of company cars, and for which the data retention period was set in the tax legislation at seven years, had an adequate legal basis and was not disproportionate in the case adjudicated. It considered in this respect that the data retained in this case did not concern data retention in the sense of the Directive, and that Digital Rights did not affect the tax legislation. It then reviewed this legislation against Art. 8 ECHR. It stated that the seven-year period was related to the not unreasonable time limit for the tax authorities to be able to assess or re-assess tax obligations of citizens, and that it was up to the legislature to attune the tax legislation with the principles of data protection.

Given the extensive reliance on telecommunications in criminal cases and law enforcement, it is questionable whether Dutch courts would easily have come to a judgment like the Court of Justice. However, once either the European Court of Justice or the European Court of Human Rights has adjudicated, Dutch courts mostly apply the reasoning of the relevant European court to cases they are confronted with.

\footnotetext{
${ }^{76}$ Evaluation of the Data Retention Directive (Evaluatie van de richtlijn gegevensbewaring), a report of the Committee to the Council and the European Parliament, (Richtlijn 2006/24/EG). Preparatory Memorandum (Senate), 2010/11, 32 797, A.

77 Joined cases C-293/12 and C-594/12 Digital Rights Ireland and Seitlinger and Others [2014] ECLI:EU:C:2014:238.

${ }^{78}$ A major example is Court of Appeal [Gerechtshof] Amsterdam, 27 May 2014, ECLI:NL: GHAMS:2014:2028.
} 
This was the case with the District Court of The Hague that rendered the Act inoperative on 11 March 2015 in summary proceedings. ${ }^{79}$ The power of civil courts to render inoperative any legislative act if it is 'manifestly unlawful' is based on case law of the Hoge Raad and extends to manifest incompatibility with directly effective provisions of treaties or of decisions of international organisations, or with directly effective EU law.

Before the Act was rendered inoperative, a Member of Parliament had presented a bill with a view to withdrawing the Act of 2009 and reinstating the prior regime. The Council of State has criticised the bill for not sufficiently distinguishing between general data and data related to the investigation of (serious) crime, thus not complying with Digital Rights sufficiently. ${ }^{80}$ The bill is pending in the Lower House (June 2016).

The Government published a preliminary draft of its own intended legislation for consultation with the general public in November 2014, which introduced a somewhat stricter judicial scrutiny prior to requesting data, a limitation to more serious criminal offences as regards the possibility to request data and the obligation to store data within the EU. This legislation was criticised by several NGOs, amongst other reasons because it still did not differentiate between the retention of general data indiscriminately and the retention of data of suspects or related to suspicions of criminal offences and the proportionality of the time limits. A year later, the Government announced that a bill had been approved by the Council of Ministers and would be submitted for advice to the Council of State. Since at the time of writing of this report (July 2016) the bill has not been introduced in Parliament, we may assume that the Council of State had objections, which the Government has not yet been able to overcome.

\subsection{Unpublished or Secret Legislation}

2.5.1 The legislation in the Netherlands concerning the publication of legislative, regulatory, delegated and executive acts is such that the principle of legal certainty prevails: citizens cannot be bound by unpublished legislation of any kind. ${ }^{81}$ The principle of publicity of legislation does not mean, however, that executive regulations that have no external effect towards citizens are not published and does not mean that they are invalid. The only effect of unpublished legislation or rules or regulations is that they cannot bind citizens.

For the purpose of the effect of international treaty provisions or of decisions of international organisations, the general rule is that they must be published in the

\footnotetext{
${ }^{79}$ Rb Den Haag, Decision of 11 March 2015, ECLI:NL:RBDHA:2015:2498.

${ }^{80}$ The bill and the advisory opinion of the Council of State are published in the parliamentary documents, Tweede Kamer, 33 939, Nos. 1-3.

${ }^{81}$ See also Sect. 3.4.1 for reference to relevant case law.
} 
Tractatenblad (the official journal in which treaties and certain decisions of international organisations are published $)^{82}$ and they are considered to have been so published as of the first day of the second calendar month after the date of issue of the relevant Tractatenblad. However, personal notification of the relevant treaty provisions (or provisions of decisions of international organisations) to the persons involved in order to bind them, is regarded as publication with regard to them if this binding effect is mentioned in the notification. ${ }^{83}$

Quasi-legislation (beleidsregels), that is to say executive regulatory acts without a basis in an Act of Parliament - usually instructions or guidelines concerning the manner in which a public authority shall exercise administrative discretion - can be relied on by citizens if they are published; they create the reasonable expectation that the relevant authority will act in accordance with the policy announced.

\subsection{Rights and General Principles of Law in the Context of Market Regulation: Property Rights, Legal Certainty, Non-retroactivity and Proportionality}

2.6.1 Here, what we mentioned above applies: once either the European Court of Justice or the European Court of Human Rights has adjudicated, Dutch courts mostly apply the reasoning of the relevant European court to cases they are confronted with, but prior to that there is a distinct deference towards the legislature. ${ }^{84}$ See also Sect. 2.8 below.

\subsection{The ESM Treaty, Austerity Programmes and the Democratic, Rule-of-Law-Based State}

2.7.1 In its advisory opinion on the approval of the ESM Treaty and the decision amending Art. 136 TFEU, the Council of State signalled that it considered the democratic control mechanisms deficient. Starting from the presumption that control mechanisms should be organised at the level of the decisions, it voiced its strong preference for a European mechanism, which national parliaments could only partially compensate for. Nevertheless, the Council of State considered the economic urgency of the matter and the choice for a common mechanism to be more important than the deficiencies that it signalled. Given the absence of involvement of the EP, the Council of State was of the opinion that there should be

\footnotetext{
${ }^{82}$ Rijkswet goedkeuring en bekendmaking verdragen (Act on the Approval and Publication of Treaties), Arts. 16-19.

${ }^{83}$ Rijkswet goedkeuring en bekendmaking verdragen, Art. 20.

${ }^{84}$ See Claes and Gerards 2012, p. 643, with references to relevant legal commentary.
} 
a guarantee in national law securing the democratic control of the acts of the minister in ESM decision-making. Furthermore, it urged the legislature to foresee that an increase of the capital could only be approved after agreement by the Parliament.

The Lower House has adopted a resolution specifying that every decision to grant financial assistance outside of the pledged amount of capital will be tabled in the Lower House because the transfer of these funds directly impacts the budgetary power of Parliament. The Government has promised to respect the resolution in a policy note on how it will involve Parliament in these decisions. Any application outside of the pledged amount of capital will be agreed with the Lower House. With respect to individual applications falling within the pledged amount, the Government will closely inform the Chamber. Legal commentators have described this 'working agreement' as an empty shell, arguing that in practice and towards the other Member States, the Government will be bound by the obligation, even if the Parliament would veto it. As such, this working agreement can only have political effects. $^{85}$

Geert Wilders, leader of the Eurosceptic and populist Party for Freedom (PVV), brought proceedings in court asking for an injunction preventing the state from approving and ratifying the ESM Treaty. At the time, the Government did not have full powers: the Government had resigned and elections were impending. The judge denied the action, holding that the claim asked him to intervene in the legislative process, which the Constitution bestows on the Government and the Parliament acting together (Art. 81 Constitution). The decision is fully in line with the very restricted role of the courts in European integration policy and political participation in the EU. ${ }^{86}$

\subsection{Judicial Review of EU Measures: Access to Justice and the Standard of Review}

2.8.1-2.8.4 Dutch courts have never claimed jurisdiction to review the constitutionality of EU secondary law. The primacy of EU law is deeply ingrained in the minds of Dutch lawyers, and it is so on grounds of the very nature of EU law. ${ }^{87}$ Even the very open norms of the Constitution concerning the applicability and primacy of international treaties are not considered applicable in this respect. Constitutional review of EU law is out of the question. There is no equivalent of Solange in the Netherlands.

More recently, scholars have spoken about the added value of the EU Charter over and beyond the ECHR. The Dutch system of fundamental rights protection is

\footnotetext{
${ }^{85}$ Diamant and van Emmerik 2013, p. 102.

86 Rb Den Haag, Decision of 1 June 2012, ECLI:NL:RBSGR:2012:BW7242.

${ }^{87}$ See e.g. Morijn et al. 2015, p. 124.
} 
highly dependent on human rights treaties, mainly the ICCPR and ECHR. The Charter is viewed as an additional tool in the hands of the Dutch courts. ${ }^{88}$ One example from the judicial practice is the case of foreigners claiming to be eligible for an asylum residence permit on grounds of their sexual orientation. The Administrative Jurisdiction Division of the Council of State, upon a preliminary reference to the ECJ, decided that if the Secretary of State holds a claimed sexual orientation for an established fact, or deems it credible, it is, according to the $X, Y$ and $Z$ decision of the Court of 7 November 2013, ${ }^{89}$ in breach of Arts. 9 and 10 of Directive $2004 / 83^{90}$ to require restraint from an applicant in giving substance to his orientation in his country of origin, even if the ECtHR seems to require restraint from an applicant if this allows him to prevent inhuman treatment. ${ }^{91}$

However, there has been at least one instance where a Dutch court, in this case the College van Beroep voor het Bedrijfsleven, ${ }^{92}$ has applied the Bosphorus ${ }^{93}$ presumption and applied only a marginal review of a decision applying EU law. ${ }^{94}$ This approach, whereby a national court would decline to review compliance with the ECHR on the basis of the Bosphorus presumption, could threaten the protection of human rights. Such a stance, however, misinterprets Bosphorus, since it concerns only the review by the ECtHR itself and presumes that the national courts and the ECJ have actually applied the EU fundamental rights standards. The case pre-dates the entry into force of the Charter, and the presumption does not seem to have been applied since.

\subsection{Other Constitutional Rights and Principles}

2.9.1 The question whether the Dutch constitutional system has a rule of parliamentary reservation of law, e.g. that penalties (also beyond criminal law), taxes, obligations, etc., must only be imposed by a parliamentary statute, and whether this

\footnotetext{
${ }^{88}$ This assumption is central to e.g. Morijn et al. 2015; Barkhuysen et al. 2011, sect. 3; Van Harten and Grootelaar 2014.

${ }^{89}$ Joined cases C 199/12 to C 201/12 X and Others [2013] ECLI:EU:C:2013:720.

${ }^{90}$ Council Directive 2004/83/EC of 29 April 2004 on minimum standards for the qualification and status of third country nationals or stateless persons as refugees or as persons who otherwise need international protection and the content of the protection granted, [2004] OJ L 304/12.

${ }^{91}$ With reference to F.G. v. Sweden, No. 43611/11, 16 January 2014 and M.E. v. Sweden, No. 71398/12, 26 June 2014.

92 The highest administrative court for social and economic matters.

${ }^{93}$ Bosphorus Hava Yollarl Turizm ve Ticaret Anonim Şirketi v. Ireland [GC], No. 45036/98, ECHR 2005-VI.

${ }^{94}$ Nevertheless, the court also emphasised that in a non-EU related case, and applying the normal standards, the ECtHR had not found a violation of Art. 6 ECHR, CBB, 24 April 2008, ECLI:NL: CBB:2008:BD0646. See also Rb Den Haag, 23 June 2009, ECLI:NL:RBSGR:2009:BJ0893 (where Bosphorus was referred to, but not applied).
} 
rule has been affected by EU/international law, is an intricate issue which has various aspects.

Briefly, the Constitution (Grondwet) reserves several issues to a parliamentary legislative act, wet. These include the restriction of the exercise of certain fundamental rights (rules on extradition (Art. 2(3) Const - which also provides that extradition can only take place pursuant to a treaty); the right to leave the country (Art. 2(4) Const); the right to vote and to be elected (Art. 5); the right to profess one's faith or belief (Art. 6(1)), although the exercise in public places can be restricted with a view to traffic safety and to prevent disorder (Art. 6(2)) on the basis of delegation by Act of Parliament; freedom of expression (Art. 7, with the exception of 'radio and television' that can be regulated pursuant to an Act of Parliament); freedom of association (Art. 8); restriction of freedom of assembly and of demonstration for any objective, while the restriction, on the basis of delegation by Act of Parliament, can only be with a view to regulate traffic and prevent disturbances of public order). Other restrictions of constitutional rights require a basis in an Act of Parliament, but if one exists, executive authorities or decentralised authorities can also restrict the exercise of those rights. Note that there is an absolute prohibition of censorship, which cannot be introduced even by Act of Parliament.

Other matters reserved for Parliament primarily concern organisational matters, e.g. concerning kingship (permission to marry, exclusion from the succession to the throne, on appointment of a successor if there is none under the constitutional rules, regency, etc.); electoral rules; personal pay and remuneration of the king, Members of Parliament and of Government; the establishment and abolition of provinces and municipalities and other public bodies; judicial procedure, etc.

There have been no specific problems raised with regard to these in the context of European integration, except the question we already mentioned concerning the currency at the time of the approval of the Maastricht Treaty. ${ }^{95}$ This is mainly because legislation as constitutionally required has been passed that provides a sufficient legal basis (such as the Act implementing the EAW Framework Decision discussed in Sect. 2.3 of this report).

There is another issue which does not regard the specific provisions of the Constitution, but the general principle of legality. In the context of criminal law this requires a prior provision in an Act of Parliament before a certain behaviour or act can be punished, as in other countries (also enshrined in Art. 16 Constitution). As a broader principle of public law, the exercise of public authority that affects the rights and duties of citizens or factually is burdensome for them, requires a basis in an Act of Parliament. There is general consensus about this.

There has been an ongoing discussion whether acts of the European Union (previously EC) are a sufficient basis. In administrative law the dominant view was and still is that a directive cannot provide such a legal basis; however, there have been differences of view as regards the question whether a regulation can provide

95 See above n. 16. 
such a basis - in particular as regards the possibility of imposing the obligation to repay (EU) subsidies if these were disbursed without legal grounds.

The brief answer on the rather complex developments in the case law is that by and large this is now also the view of the courts. In particular, administrative courts assume that a national public authority can derive powers from primary EU law directly, although it is mainly national law that determines which national authority is competent; moreover, national law can regulate the manner in which this authority exercises its powers. Apart from certain powers being assumed or granted under EU law (which generally addresses Member States, not specific authorities), it may in practice be required that there is a national legal basis in an Act of Parliament for empowering a public authority (sometimes referred to as double legality).

With regard to secondary EU law the courts and academic doctrine hold that a directive cannot be the exclusive basis of a public authority's powers; there must be an Act of Parliament that determines which public authority can hold a power that may exist in EU law. The same view still prevails as regards regulations, but recent case law of the Council of State and the College van bestuur voor het bedrijfsleven (The Trade and Industry Appeals Tribunal, also known as Administrative High Court for Trade and Industry) ${ }^{96}$ suggests that if an obligation exists under EU law, a material competence under EU law is presumed and can suffice to render an authority competent.

\subsection{Common Constitutional Traditions}

The particular nature of the Netherlands constitution, comprising not only the Grondwet but also human rights treaties that form an integral part of it - especially the ECHR and the UN Conventions - suggests that the commonality of constitutional traditions is in a sense incorporated into the constitutional body of fundamental rights norms. Nevertheless, it is useful to note that the provisions of international human rights treaties are meant as minimum norms, with the exception of the treaties that provide peremptory norms from which no derogation is possible, such as the UN Conventions on Genocide and on Torture. Specific norms contained in the Constitution with a higher level of protection are the absolute prohibition of censorship under Art. 7 of the Grondwet, and the right to equal financial treatment of both public and private schools (Art. 23 Grondwet). These are not matched by the human rights treaties nor can they be said to be common to the constitutional fundamental rights acquis of the other EU Member States. We can say that the supplementary role that the common constitutional traditions are assigned under Art. 6(3) TEU can contribute to the dynamics of fundamental rights protection in

\footnotetext{
${ }^{96}$ This is a specialised administrative court which rules on disputes in the area of social-economic administrative law, including competition law and telecommunications law.
} 
Europe. For instance, the very restricted scope for prior permission to publish certain expressions in the case law of the ECtHR is probably inspired by the fact that this is absolutely prohibited in countries like Germany and the Netherlands. This ECtHR case law in turn translated into the ECJ taking a much more protective line than the Court of First Instance in the Connolly cases. ${ }^{97}$ Similarly, changing attitudes towards equal treatment and non-discrimination, for instance on the basis of sexual orientation, leading to acknowledgment of same sex marriage - controversial as it may be - may also be an example of a certain dynamic that translates into changed conceptions of rights protection in the European and EU context. Perhaps the German understanding of the right to privacy in the sense of data protection is a more important and better example. Thus, what at one moment in time is a specific national understanding may either lead to a broader consensus translating into European and EU law, or to the ECJ picking up on it, creating a broader common constitutional tradition subsequently.

The dynamics can also go in another direction, as Melloni shows. The Spanish Constitutional Tribunal chose to abandon its more protective standard of a fair trial - the right to retrial after conviction in absentia - to the standard that the ECJ determined to be the uniform EU standard, also outside the scope of EU law. ${ }^{98}$

\subsection{Article 53 of the Charter and the Issue of Stricter Constitutional Standards}

2.11.1 As explained, the ECHR is of special importance in the Dutch legal system of fundamental rights protection, given the prohibition of judicial constitutional review. Review in the light of directly effective treaty provisions is the only tool in the hands of courts to review primary legislation. When conducting such review on the basis of Art. 94 of the Constitution, judges remain very well aware of another provision in the Constitution, Art. 120, which institutes a ban on constitutional review. Accordingly, the courts are reluctant to interpret the ECHR broadly and to offer higher protection than follows from the case law of the ECtHR. Indeed, Art. 94 allows courts to disapply provisions of primary legislation only when such application is incompatible with directly effective provisions. The courts feel that only the interpretation given by the ECtHR makes such application incompatible, not their own more stringent reading of the ECHR. Accordingly, the courts consider themselves bound by the interpretation of Strasbourg, and the ECHR minimum

\footnotetext{
${ }^{97}$ Case C-274/99 P Connolly v. Commission [2001] ECR I-01611, as compared to the CFI in the same case Joined cases T-34/96 and T-163/96 [1999] FP-I-A-00087; FP-II-00463.

${ }^{98}$ See Besselink 2014a.
} 
standard tends to become the national maximum standard. ${ }^{99}$ Article 53 ECHR thus does not lead to higher judicial standards in the Netherlands. There are only a few aspects of the national constitutional human rights protection that are considered to offer more protection than the ECHR, namely with respect to constitutional provisions usually allowing restrictions on constitutional rights only if they are based on an Act of Parliament, and in some cases further limited to only a few public policy objectives, such as public order and safety in the clause on the protection freedom of religion (Art. 6(2) Constitution). Yet, this is of little avail to individuals seeking protection against primary legislation, given that the courts are prohibited from reviewing Acts of Parliament against the provisions of the Constitution, if the constitutionality depends on the compatibility of an Act of Parliament with the Constitution. Only if this is not the case, for instance when it concerns the compatibility of municipal by-laws with the more limited range of objectives for which certain fundamental rights can be restricted as compared with the ECHR, the national courts can provide more protection than the ECHR. In this regard the absolute prohibition of censorship in Art. 7 of the Constitution, which prohibits prior permission for any expression whatsoever, is also worth mentioning, as it goes further than Art. 10 ECHR. Although the latter provision does not as such prohibit censorship, the ECtHR allows for the requirement of prior permission, albeit in exceptional circumstances, whereas under the Netherlands Constitution prior permission cannot be allowed under any circumstances at all.

It is important to emphasise that Art. 53 Charter does not automatically make the ECHR minimum the maximum standard. Article 53 Charter does allow for higher protection on national constitutional grounds, unless such higher protection would amount to an infringement of EU law.

For the moment, the Charter is seen as increasing the protection of individuals in the Netherlands, rather than threatening the national protection. However, given the importance of the ECHR in the Dutch legal order, a lowering of the ECHR standards would be considered problematic. Yet, in light of Art. 52 of the Charter, the level of protection in EU law (whether in the Charter or primary or secondary EU law) should never fall below the minimum standard of the ECHR.

\section{Constitutional Issues in Global Governance}

\subsection{Constitutional Rules on International Organisations and the Ratification of Treaties}

3.1.1-3.1.3 Participation in the European Union, the ratification of the European (amendment) Treaties and the effect of EU law in the domestic legal order have

\footnotetext{
${ }^{99}$ See Hoge Raad, 10 August 2001, ECLI:NL:HR:2001:ZC3598; see more generally, Gerards 2010.
} 
always been based on the general provisions concerning international treaties and international organisations. The same rules of Arts. 90-94 thus apply. Powers can be conferred on international organisations by recourse to international treaties, which require simple majority approval in Parliament, unless they deviate from the Constitution or necessitate such deviation. If that should be the case, approval requires a two-thirds majority of the votes cast. The procedure has been followed in the case of the EDC Treaty, the Treaty of 15 August 1962 with Indonesia concerning Western New Guinea and for the approval of the Statute of Rome concerning the International Criminal Court (ICC). In the latter case, the Government did not consider the treaty as 'deviating from the Constitution or necessitating such deviation', but the Council of State opined that it did. The Government tabled the Approval Act on the basis of Art. 91(3) 'to the extent necessary'. The Act did not specify to what extent the treaty deviated from the Constitution, and did not stipulate the precise provisions of the Constitution from which the treaty could supposedly deviate.

These treaties did not require prior amendment of the Constitution. In the case of a conflict between a treaty in force and the Constitution, the former takes precedence.

Given the liberal and open approach to international cooperation, there has not been a need to incorporate specific provisions in the Constitution with respect to the ECHR, NATO, the ICC or any other international organisation.

\subsection{The Position of International Law in National Law}

3.2.1-3.2.2 On the basis of Arts. 93 and 94 of the Constitution, provisions of treaty law that are 'binding on anyone' can be directly applied in the domestic legal order, and must be awarded priority over all provisions of national law, including the Constitution. The case law suggests that the expression 'binding on anyone' is equivalent to 'direct effect' as we know it in EU law.

The doctrine of direct effect has as a consequence that citizens cannot be bound by international norms that do not create rights or obligations for citizens directly, and to that extent can be said to protect citizens from the mutual understandings, technical or general as they might be, that might impose obligations. This could be done either by the competent state institutions like the legislature or in some cases the executive. But compliance with international agreements could also voluntarily or unilaterally be secured through private behaviour. Thus, compliance with international technical standards by industry can be achieved without state (legislative or executive) intervention. Similarly, international or transnational understandings between non-state actors can be effectuated without recourse to state intervention - whether it be the Internet Corporation for Assigned Names and Numbers (ICANN) standards on internet domain names, or accounting standards 
issued by the International Accounting Standards Board (IASB). This has always been the case, and remains so a fortiori in the context of a globalising economy and social environment.

\subsection{Democratic Control}

3.3.1 We have to distinguish between democratic control as regards governmental activities in negotiating treaties and its contribution to decision-making within international organisations established by treaties on the one hand, and democratic control over international governance and rule-making in which either government officials are involved together with non-state actors or in which there is no involvement of the Government or its officials.

Democratic control is constitutionally exercised through parliamentary institutions over the first category of acts. The Government is under the obligation to inform Parliament of the treaties it negotiates under the Act on the Approval and Publication of Treaties (Art. 1), and does this periodically by submitting a list of instruments that have been negotiated with an indication of the objective and whether they concern a politically sensitive or important matter. The practice of both the Lower House and Upper House as to the scrutiny of this list leaves much to be desired; often there is no more (and often less) than a superficial consultation between a committee of the House with the Minister of Foreign Affairs. ${ }^{100}$ As was mentioned in Sect. 3.1, both Houses have to approve each treaty.

As regards the scrutiny of decision-making within international organisations other than the European Union, there is hardly any systematic parliamentary activity, even though decisions can be directly effective and then have priority over any conflicting legislation.

As regards the second type of activity, that is to say international governance and rule-making beyond the state, it may be useful at the outset to recall the consociationalist tradition of the Dutch constitutional tradition, in which democratic institutions had broad and deep foundations in society and its structures, well beyond the state as such (see Sect. 1.3 above). This has meant that certain democratic institutions, such as political parties and the media, have traditionally not been associated, let alone identified, with the state. 'Self-regulation' by sectors of the economy and non-state public actors, such as trade unions and employers organisations, both by themselves and together have been regarded as equivalent to state regulation. This has been officially promoted for instance in the fields of labour relations, wages, targets for employment of disadvantaged groups such as women or persons with disabilities, and in some cases sanctioned by state institutions, such as the legislature and the Government. Informal forms of governance beyond the state are an old phenomenon in the Netherlands. Resources of legitimacy have thus

${ }^{100}$ For a critical analysis, see Besselink 2007. 
traditionally not been identified with the state, and this might contribute to a relative openness to globalisation and its legitimacy, which suits the Netherlands well in as much as its economy is one of the most exposed to the international financial, social, technological, fiscal and trade environment.

There is obviously a potential problem with this approach that can be put in terms of the medieval canon law adage quod omnes tangit ab omnibus approbari debet, that can already be found in the Codex Iustiniani, ${ }^{101}$ where it applied within private law, but was extended to the public sphere by the conciliarist canon lawyers in the eleventh and twelfth centuries: who are the omnes that are affected and must approve? What standard of being affected should apply? Are 'all that are affected' only the direct 'stakeholders' that are actually affected, or should this include those who are potentially affected? Or are in a democracy all citizens stakeholders, and all citizens to be considered as actually or potentially affected?

The broadest democratic understanding of globalisation would require parliamentary involvement in the scrutiny of international decision-making in which the Government or its officials are involved, but parliamentary involvement might also be required with regard to the forms of rule-making and governance beyond the state, at any rate when Government or its functionaries are involved in making them, that is to say in hybrid forms of informal rulemaking and governance. This, however, is requiring more than a parliament like the States General of the Netherlands at present is aware of. Hence, globalisation has lead on the one hand to the appeal of certain scholars in the field of public administration to abolish the Parliament. ${ }^{102}$ On the other hand, there are pleas for more parliamentary awareness and attention to systematic scrutiny of international governance and decision-making in the ever denser and less transparent web of ministers, diplomats and civil servants in formal and informal networks, which should be paired with a more systematic parliamentary follow-up of the work that is already done by parliamentary delegations to such institutions as the World Bank and the IMF's Parliamentary Network, ${ }^{103}$ the Netherlands parliamentary delegations that every year form part of the delegation to the United Nations, and the delegations that are members of the NATO and Council of Europe Parliamentary Assemblies. ${ }^{104}$

101 'CJ.5.59.5.2: Imperator Justinianus. Tunc etenim, sive testamentarii sive per inquisitionem dati sive legitimi sive simpliciter creati sunt, necesse est omnes suam auctoritatem praestare, ut, quod omnes similiter tangit, ab omnibus comprobetur.' ([On guardianship.] Emperor Justinian. For in such cases [acts of guardianship that dissolve the guardianship] the guardians, whether testamentary statutory or appointed with or without inquiry, must all give their consent, so that what touches all, must be approved by all.) Translation by Fred Blume, http://uwdigital.uwyo.edu/ islandora/object/wyu\%3A45047\#page/284/mode/2up/search/5-59.

102 In 't Veld, R. (2002, March 22). Volksvertegenwoordiging moet worden afgeschaft (Parliament should be abolished). NRC Handelblad.

103 See http://www.parlnet.org/about.

${ }^{104}$ See Besselink, above n. 98, part III. 


\subsection{Judicial Review}

3.4.1 Here also we distinguish between forms of international law that exist under treaty law and informal international or transnational law that is made by non-state actors.

Public international law: educational sanctions against Iran As regards the first, a good example of the Dutch courts taking a 'constitutionalist' approach to international law is when they adjudicated the implementation of UN sanctions against Iran under Security Council Resolution 1737. This Resolution under Chapter VII of the UN Charter contains a paragraph in which the Council '[c]alls upon all States to exercise vigilance and prevent specialized teaching or training of Iranian nationals, within their territories or by their nationals, of disciplines which would contribute to Iran's proliferation sensitive nuclear activities and development of nuclear weapon delivery systems'. The EU adopted a Common Position on 27 February 2007 which provides that the Member States shall, in accordance with their national legislation, take the necessary measures to prevent specialised teaching or training of Iranian nationals, within their territories or by their nationals, of disciplines which would contribute to Iran's proliferation sensitive nuclear activities and to the development of nuclear weapon delivery systems. ${ }^{105}$

This was implemented by a sanctions measure which prohibited access to data and locations mentioned in a list, and the provision of specialised, nuclear proliferation sensitive education to Iranian nationals, with the exception of academic undergraduate studies, unless exempted by the Minister. Perhaps this very strict sanctions regime was inspired by the fact that in the early 1970s, Abdul Qadeer Khan was trained in the Netherlands and put his expertise into developing the nuclear bomb for Pakistan. He also offered the designs to other states, allegedly Libya, North Korea, Iran and China, as well. However that may be, in the Iranian sanctions case the courts struck down the finding that the measure unlawfully discriminated between Iranian students and non-Iranian students unnecessarily and in an unjustified manner that is contrary to Art. 26 ICCPR and the ECHR (Art. 14 in connection with Protocol no. 1, Art. 2 and Protocol no. 12). The Hoge Raad held that the Security Council Resolution as well as the EU Common Position were binding and directly effective on the basis of Art. 94 Constitution, but indicated that the sanctions had to be in conformity with national law. It left an amount of discretion as to how to achieve the aims of the Resolution, thus necessitating acting in conformity with such international obligations as are contained in the ECHR and ICCPR.

\footnotetext{
${ }^{105}$ Article 6, Council Common Position 2007/140/CFSP of 27 February 2007 concerning restrictive measures against Iran, [2007] OJ L 61/49.
} 
The Hoge Raad explicitly referred to the Court of Justice's judgment in Kadi I, ${ }^{106}$ as the courts of lower instance had done. This confirms again that Dutch courts are prepared to take constitutionalist concerns into account by relying primarily on international human rights sources, in particular if they can find some precedent in the case law of the European Courts or other authoritative international bodies.

Informal international law: technical standards Many informal standards and rules that have been developed in a transnational context by non-state actors are of a technical nature, whatever the field of application of those standards. ${ }^{107,108}$ Many of the standards in the field of finance are turned into hard law via EU law, for instance the Basel Committee's standards on banking solvency, the International Organization of Securities Commission's (IOSCO) standards on trading in stock and financial trading instruments and the IASB standards on accounting have found their way into the EU Capital Requirement Directive, the Prospective Directive, the Markets in Financial Instruments Directive and the International Accounting Standards Regulation. These are then implemented or directly applied domestically.

As far as the informal international output is not mediated through EU law, the constitutional rules determining the position of formal international law in the national legal order are not really applicable in as much as these relate to treaty or treaty based law. Yet, these informal standards are applied also in law, even in the case law of the highest courts, although often this is most evident in the opinions of the Advocate General to the Hoge Raad. None of these cases have concerned in any manner a conflict between domestic law and the applicable standard, but have always involved the application of an international standard in order to determine the appropriate, but open or vague domestic legal norm. ${ }^{109}$

Finally, we may refer to the Dutch case law on the principle of publicity of legislation ${ }^{110}$ of standards that are developed by private actors (often based on international standards or agreements) to which national legislation refers, thus rendering the private standard binding on everyone. This illustrates the approach

\footnotetext{
106 Joined cases C-402/05 P and C-415/05 P Kadi and Al Barakaat International Foundation v. Council and Commission [2008] ECR I-06351.

${ }^{107}$ Hoge Raad 14 December 2014, ECLI:NL:HR:2012:BX8351.

${ }^{108}$ On private and hybrid standard setting in the Netherlands (and its elation to international and European standard setting by the ISO and ESO), Stuurman 1995; Evers 2002; Evers 1999, pp. 1814-1815; Stuurman and Wijnands 2002.

${ }^{109}$ For a case study on the Netherlands with regard to standards issued by the Basel Committee, IOSCO and IASB, see Besselink 2012b. Case law applying standards in this field is Hoge Raad, 25 November 2005, LJN: AU2275; Hoge Raad 24 April 2009, LJN: BG8790; references, sometimes elaborately, by the Advocate-General in HR 13-11-2009, LJN: BG5866; HR 16-11-2007, LJN:AZ7371. A case concerning the liability of the DNB as successor to the supervisory agency Verzekeringskamer, is Hoge Raad, C04/279HR 13-10-2006, LJN: AW2077, in which it concludes to a marginal form of review, taking into account the discretion of the supervisor. The Advocate-General in this case explicitly referred to the first of the Basel Committee's 'Core Principles for Effective Banking Supervision', concerning 'legal protection' for the supervisors as a starting point for the assessment of liability.

${ }^{110}$ See also Sect. 2.5 above.
} 
taken to private regulation. In the leading case on this matter, Knooble ${ }^{111}$ the issue was that a technical standard that was legally binding on architects and builders was available only after payment of a considerable sum of money to the standardisation institute involved, the Netherlands Standardizaton Institute (NEN), whose major income derives from such payments. Knooble complained in court that by legislative reference to the relevant NEN-standards, these became binding on private citizens; however, these have not been published in conformity with the Constitution and organic legislation on the publication of legislative acts, and hence were not binding on it. At first instance the District Court of The Hague held that indeed the relevant standards became legislation and hence would need to be published in accordance with the relevant constitutional and legislative provisions, in the absence of which they could not be binding. On appeal, the Court of Appeal of The Hague reversed this judgment. The reversal was upheld by the Hoge Raad. It considered that the references in the applicable legislation did not render the standards binding legislation: the NEN-standards have not been set by a body pursuant to a legislative power attributed or delegated to it by the Constitution or an Act of Parliament, and are hence not legislative acts which need to comply with the applicable rules on publication and accessibility of legislative acts. ${ }^{112,113}$ Significantly, the Hoge Raad added that although the standards are not legislative in character, they are indeed 'norms' that are generally binding on private parties. ${ }^{114}$ This confirms the view that citizens can be bound both by official legislation as well as by privately established norms that are generally binding by reference to them in official legislation.

\subsection{The Social Welfare Dimension of the Constitution}

3.5.1 The Netherlands has a set of social rights provisions in the first chapter of the Constitution, and is a party to all human rights instruments that guarantee social rights, both in the UN and European contexts. However, the legal status of these rights is quite weak. Neither the national constitutional nor the international social rights provisions are deemed enforceable in court and they are generally considered to not be directly effective. In the political discourse, with few exceptions, these rights do not play a prominent role, and usually only play any role at all in a rather distant background.

\footnotetext{
111 District Court The Hague 31 December 2008, ECLI:NL:RBSGR:2008: BG8465; Court of Appeal The Hague 16 November 2010, ECLI:NL:GHSGR:2010:BO4175; Hoge Raad [Supreme Court] 22 June 2012, ECLI:NL:HR:2012:BW0393 respectively.

112 Ibid., para. 3.8.

113 The Netherlands Raad van State [Council of State] reached a similar conclusion in a case decided on 2 February 2011, ECLI:NL:RVS:2011:BP2750.

${ }^{114}$ HR 22 June 2012, para. 3.12.
} 
One exception might be the debate in 2014 and 2015 on the most minimal support for illegal migrants that have lost the right to remain and are supposed to leave the country, the so-called 'bed, bath and bread' facility, which even nearly led to a cabinet crisis in 2015 .

In decisions of the European Committee of Social Rights, the supervisory committee of the European Social Charter (published 1 November 2014), in two cases brought by the Council of European Churches v. the Netherlands (No. 90/ 2013) and the European Federation of National Organisations working with the homeless (FEANTSA) v. the Netherlands (No. 86/2012), the Committee held that withholding food, water, housing and clothes from aliens who are not lawfully residing in the Netherlands is an infringement of Art. 13(4) and 31 of the European Social Charter.

Although these provisions of the European Social Charter are not directly effective in the sense of Art. 94 Constitution, nor are the views of the Committee legally binding, the Centrale Raad van Beroep, the competent highest administrative court, decided that the views of the Committee must be taken into account in its interpretation and application of Arts. 3 and 8 ECHR. On that basis it gave an injunction to provide for a basic arrangement of facilities, to wit a shower, a bed for the night, breakfast and an evening meal ('bed, bath and bread') during a period of two months in relevant cases. ${ }^{115}$ This case law necessitated a policy change for the Government of the day, which nearly collapsed under the divergences within the coalition over the details of arranging for the minimum facility, which was overcome by a political compromise, the details of which remain unclear in practice, but which gives municipalities leeway to provide minimum support.

\section{References}

Barkhuysen T., Bos A.W., ten Have F. (2011) Een verkenning van de betekenis van het Handvest van de Grondrechten van de Europese Unie voor het privaatrecht. Deel 2: De verhouding van het Handvest tot het EVRM en de meerwaarde van het Handvest (An exploration of the meaning of the Charter of Fundamental Rights of the European Union for private law). Nederlands Tijdschrift voor Burgerlijk Recht (NTBR) 28(10):547-557.

Besselink L.F.M. (2002-2003) De constitutionele bepalingen over verdragen die van de Grondwet afwijken en de opdracht van bevoegdheid aan internationale organisaties (The constitutional provisions on treaties that diverge from the Constitution and on the attribution of powers to international organisations). Kamerstuk [Parliamentary Document] 27484 (R 1669), 20022003, nr. 289, second reprint.

Besselink L.F.M. (2003) Becoming a party to treaties which diverge from the Constitution. EPL 9 (4):471-480.

${ }^{115}$ Centrale Raad van beroep 17 December 2014, ECLI:NL:CRVB:2014:4259. 
Besselink L.F.M. (2004a) Constitutional Law of The Netherlands. Ars Aequi Libri, Nijmegen.

Besselink L.F.M. (2004b) The Kingdom of the Netherlands: the Charter and Constitution. Ars Aequi Libri, Nijmegen.

Besselink L.F.M. (2007) Parlement en buitenlandse politiek - Een drieluik over constitutionele relaties tot de buitenwereld (Parliament and foreign policy: a triptych on constitutional relations with the world outside). In: Publikaties van de Staatsrechtkring - Staatsrechtconferenties (Publications of the Constitutional Law Society - The Constitutional Law Conferences), volume 10. Wolf Legal Publishers, Nijmegen, pp. 177-204.

Besselink L.F.M. (2012a) The Parliamentary Legitimacy of the European Union: The Role of the States General in the European Union. Utrecht Law Review 8(1):28-50.

Besselink L.F.M. (2012b) Informal International Lawmaking: Elaboration and Implementation in The Netherlands. In: Berman A., Duquet S., Joost Pauwelyn J., Wessel R.A., Wouters J. (eds.) Informal International Lawmaking: Case Studies. Torkel Opsahl Academic EPublisher, The Hague, 97-140. E-published at http://www.fichl.org/fileadmin/fichl/documents/LOTFS/ LOTFS_3_Web.pdf.

Besselink, L.F.M. (2014a) Parameters of Constitutional Conflict after Melloni. E.L.Rev. 39(4):531-552.

Besselink L.F.M. (2014b) The Kingdom of the Netherlands. In: Besselink L.F.M., Bovend'eert P., Broeksteeg H., de Lange R., Voermans W. (eds.) Constitutional Law of the EU Member States. Kluwer, Deventer, pp. 1189 et seq.

Claes M., Gerards J. (2012) The Netherlands. In: Laffranque J. (ed.) The Protection of Fundamental Rights Post-Lisbon, Reports of the XXV FIDE Congress Tallinn 2012, Vol. 1. Tartu University Press, Tallinn, pp. 641-704.

De Vries S. (2016) Grondrechten binnen de Europese interne markt: een tragikomisch conflict tussen waarden in de 'Domus Europaea' (Fundamental rights within the internal market: a tragicomedy on a conflict of values in the 'domus europaea'). SEW tijdschrift voor Europees en economisch recht 44(3):99-109.

De Witte B. (2004) Do Not Mention the Word: Sovereignty in Two Europhile Countries: Belgium and The Netherlands. In: Walker N. (ed.), Sovereignty in Transition. Hart Publishing, Oxford.

Diamant M., van Emmerik M.L. (2013) Het Nederlandse budgetrecht Europees perspectief (The power of the purse under Dutch constitutional law in European perspective). Tijdschrift voor Constitutioneel Recht 4(2):94-129.

Dooyeweerd H. (1984), A New Critique of Theoretical Thought, (4 vols.), Philadelphia 19531957. Reprint Paideia Press, Ontario.

Eijsbouts W.T. (2014) Rutte onaardig, onwaardig, schaamteloos (Prime Minister Rutte unkind, undignified, shameless) Hogendorp Centrum, Amsterdam 2014.

Evers G.J. (2002) Blind vertrouwen? Een onderzoek naar de toepassing van certificatie ten dienste van de handhaving van wettelijke voorschriften (Blind Trust? A study of the use of certification and standardisation for the enforcement of legal requirements). Boom Juridisch Uitgevers, The Hague.

Evers G.J. (1999) Een normalisatienorm is geen algemeen verbindend voorschrift (A normalisation rule is not a generally binding regulation). Nederlands Juristenblad NJB 38:1814-1815.

Gerards J.H. (2010) Samenloop van nationale en Europese grondrechtenbepalingen - hoe moet de rechter daarmee omgaan? (Concurrence of national and European fundamental rights provisions). Tijdschrift voor Constitutioneel Recht 3:224-255.

Glerum V.H. (2013) De weigeringsgronden bij uitlevering en overlevering: een vergelijking en kritische evaluatie in het licht van het beginsel van wederzijdse erkenning (Grounds for refusal in extradition and surrender cases: a comparison and critical evaluation in light of the principle of mutual recognition). Wolf Legal Publishers, Nijmegen. 
Heringa A.W. (1992) De verdragen van Maastricht in strijd met de Grondwet. Goedkeuring met twee derde meerderheid? (The Maastricht Treaties are in conflict with the Constitution. Approval by two-thirds majority?). Nederlands Juristenblad NJB 67(24):749-866.

Kortman, C.A.J.M. (2008) Wegwerprecht, oude dame of frisse juf?, De Grondwet herzien. 25 jaar later, 1983-2008 (Disposable law, old lady or young damsel?), pp. 7-25. E-published at https://www.rijksoverheid.nl/binaries/rijksoverheid/documenten/rapporten/2008/04/11/degrondwet-herzien-25-jaar-later/boekgrondwetherzienjanuari.pdf.

Kurtovic E., Langbroek P. (2010) Uitgeleverd aan overlevering? De Nederlandse overleveringspraktijk beschreven, gevolgd door een discussie over de effectuering van fundamentele rechten van verdachten en veroordeelden (Handed over to surrender? The Dutch surrender practice described, followed by a discussion of the effectiveness of the fundamental rights of suspects and convicted persons). Delikt en Delinkwent 40(7):831-856.

Kuyper A. (1880) Soevereiniteit in eigen kring (Sovereignty within one's own sphere). JH Kruyt, Amsterdam.

Malewicz R. (2006). De Overleveringswet in de praktijk (The Act on Surrender in practice). Strafblad 2006(6):491-499.

Möllers C. (2011) Legalität, Legitimität und Legitimation des Bundesverfassungsgerichts. In: Möllers C., Jestaedt M., Lepsius O., Schönberger C. (eds.) Das entgrenzte Gericht. Eine kritische Bilanz nach sechzig Jahren Bundesverfassungsgericht. Suhrkamp, Berlin, pp. 283408.

Morijn J. (2006) Balancing Fundamental Rights and Common Market Freedoms in Union Law: Schmidberger and Omega in the Light of the European Constitution. ELJ 12(1):15-40.

Morijn J., Pahladsingh A., Palm H. (2015) Vijf jaar bindend Handvest van de Grondrechten: wat heeft het de rechtzoekende opgeleverd? (What has five years of the binding Charter of Fundamental Right brought the litigant?) Nederlands Tijdschrift voor Europees Recht NTER, 2015(4):123-133.

Oomen B. (2009) Constitutioneel bewustzijn in Nederland: Van burgerschap, burgerzin en de onzichtbare Grondwet (Constitutional awareness in the Netherlands: on citizenship, civic responsibility and the invisible Constitution). Recht Der Werkelijkheid, 30(2):55-79.

Oomen B., Lelieveldt H. (2008) Onbekend maar niet onbemind: Wat weten en vinden Nederlanders van de Grondwet? (Unknown but not unliked: what do Dutchmen know about the Constitution and what do they think of it?). Nederlands Juristenblad NJB, 83(1):577-578.

Royal Committee on the Constitution (2010) Rapport Staatscommissie 2010. E-publication at https://www.rijksoverheid.nl/documenten/rapporten/2010/11/11/rapport-staatscommissiegrondwet.

Sanders H. (2011) Handboek overleveringsrecht. Intersentia, Antwerpen/Cambridge.

Sanders H., Overlevering (Surrender). Delike en Delinkwent 42(24):247-256.

Stuurman C. (1995) Technische normen en het recht (Technical standards and the law). Kluwer, Deventer.

Stuurman C., Wijnands H.S.A. (2002) Legal Aspects of Standardisation in the Netherlands. In: Falke J., Schepel H. (eds.) Legal Aspects of Standardisation in the Member States of the EC and EFTA, Volume 2, Country Reports. Office for Official Publications, Luxemburg, pp. 557624.

Van Harten H., Grootelaar H. (2014) Doorwerking van het Handvest van de Grondrechten van de Europese Unie in de Nederlandse rechtspraak: een kwantitatieve stand van zaken (The effect of the Charter of Fundamental Rights of the European Union in the Dutch case law: a quantitative state of affairs). Nederlands Tijdschrift voor de Mensenrechten, NTM-NJCMBull (39):182200. 
Open Access This chapter is licensed under the terms of the Creative Commons Attribution 4.0 International License (http://creativecommons.org/licenses/by/4.0/), which permits use, sharing, adaptation, distribution and reproduction in any medium or format, as long as you give appropriate credit to the original author(s) and the source, provide a link to the Creative Commons license and indicate if changes were made.

The images or other third party material in this chapter are included in the chapter's Creative Commons license, unless indicated otherwise in a credit line to the material. If material is not included in the chapter's Creative Commons license and your intended use is not permitted by statutory regulation or exceeds the permitted use, you will need to obtain permission directly from the copyright holder.

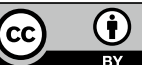

